\title{
A global threats overview for Numeniini populations: synthesising expert knowledge for a group of declining migratory birds
}

\author{
JAMES W. PEARCE-HIGGINS, DANIEL J. BROWN, DAVID J. T. DOUGLAS, \\ JOSÉ A. ALVES, MARIAGRAZIA BELLIO, PIERRICK BOCHER, \\ GRAEME M. BUCHANAN, ROB P. CLAY, JESSE CONKLIN, \\ NICOLA CROCKFORD, PETER DANN, JAANUS ELTS, CHRISTIAN FRIIS, \\ RICHARD A. FULLER, JENNIFER A. GILL, KEN GOSBELL, \\ JAMES A. JOHNSON, ROCIO MARQUEZ-FERRANDO, JOSE A. MASERO, \\ DAVID S. MELVILLE, SPIKE MILLINGTON, CLIVE MINTON, TAEJ MUNDKUR, \\ ERICA NOL, HANNES PEHLAK, THEUNIS PIERSMA, FRÉDÉRIC ROBIN, \\ DANNY I. ROGERS, DANIEL R. RUTHRAUFF, NATHAN R. SENNER, \\ JUNID N. SHAH, ROB D. SHELDON, SERGEJ A. SOLOVIEV, \\ PAVEL S. TOMKOVICH and YVONNE I. VERKUIL
}

\begin{abstract}
Summary
The Numeniini is a tribe of 13 wader species (Scolopacidae, Charadriiformes) of which seven are Near Threatened or globally threatened, including two Critically Endangered. To help inform conservation management and policy responses, we present the results of an expert assessment of the threats that members of this taxonomic group face across migratory flyways. Most threats are increasing in intensity, particularly in non-breeding areas, where habitat loss resulting from residential and commercial development, aquaculture, mining, transport, disturbance, problematic invasive species, pollution and climate change were regarded as having the greatest detrimental impact. Fewer threats (mining, disturbance, problematic native species and climate change) were identified as widely affecting breeding areas. Numeniini populations face the greatest number of non-breeding threats in the East Asian-Australasian Flyway, especially those associated with coastal reclamation; related threats were also identified across the Central and Atlantic Americas, and East Atlantic flyways. Threats on the breeding grounds were greatest in Central and Atlantic Americas, East Atlantic and West Asian flyways. Three priority actions were associated with monitoring and research: to monitor breeding population trends (which for species breeding in remote areas may best be achieved through surveys at key non-breeding sites), to deploy tracking technologies to identify migratory connectivity, and to monitor land-cover change across breeding and non-breeding areas. Two priority actions were focused on conservation and policy responses: to identify and effectively protect key non-breeding sites across all flyways (particularly in the East Asian- Australasian Flyway), and to implement successful conservation interventions at a sufficient scale across human-dominated landscapes for species' recovery to be achieved. If implemented urgently, these measures in combination have the potential to alter the current population declines of many Numeniini species and provide a template for the conservation of other groups of threatened species.
\end{abstract}




\section{Introduction}

Globally, biodiversity faces growing pressure, leading to increased extinction risk across taxa (Butchart et al. 2010). For birds, 13\% of species are regarded as globally threatened with extinction, whilst a further $9 \%$ are listed as 'Near Threatened' (BirdLife International 2015b). Habitat loss, over-exploitation and invasive non-native species are considered the main threats facing these species, although the impacts of these threats vary between populations, and are often poorly documented or understood (BirdLife International 2010). Identifying the principal drivers of population declines is an essential precursor to any conservation action (Gibbons et al. 2011), but is often challenging due to a lack of resources, ecological information, monitoring data and published research. Determining how threats affect populations can be particularly problematic for migratory species, as they face multiple threats at different stages of their annual cycle. Long-distance migrants are in particular decline globally (Robbins et al. 1989, Sanderson et al. 2006, Yamamura et al. 2009); yet 91\% are inadequately protected across their annual cycle (Runge et al. 2015).

Here, we suggest how some of the challenges that make assessing the threats facing migratory species difficult, can be overcome using an expert-based assessment of the global threats to Numeniini as an example. The Numeniini is a highly threatened paraphyletic tribe of waders or shorebirds (hereafter waders) within the suborder Scolopaci (Gibson and Baker 2012). The tribe occurs on all continents except Antarctica, although their breeding ranges are restricted to the Northern Hemisphere (Piersma et al. 1996, Colwell 2010). Most species within the tribe are large-bodied with a relatively delayed age of maturity, low fecundity and high survival rates (Piersma and Baker 2000). The tribe includes seven species of conservation concern (BirdLife International 2015b); two are listed as 'Critically Endangered' (Eskimo Curlew Numenius borealis and Slender-billed Curlew N. tenuirostris) of which at least the Eskimo Curlew is considered likely to be extinct (Roberts and Jarić 2016), one as 'Endangered' (Far Eastern Curlew N. madagascariensis), one as 'Vulnerable' (Bristle-thighed Curlew N. tahitiensis), and three as 'Near Threatened' (Eurasian Curlew N. arquata, Bar-tailed Godwit Limosa lapponica and Black-tailed Godwit L. limosa). Populations of six species can be further divided into 30 separate populations or subspecies (Table 1 ), many of which have different requirements and migratory strategies, increasing the challenge of conservation at the species level. Populations of the same species may also be subject to contrasting pressures, and some, such as Steppe Whimbrel N. phaeopus alboaxillaris, are therefore highly threatened even if the species as a whole is not (Brown et al. 2014). Many populations are long-distance migrants, including the Bar-tailed Godwit Limosa lapponica baueri which undertakes the longest non-stop migration of any landbird (Gill et al. 2009). Given that half of this tribe is of conservation concern, the main aim of this work is to understand the threats that they face around the world, taking advantage of the fact that a number of species occur in discrete populations across different flyways, in order to reduce the likelihood of future extinctions amongst the remaining species. The results of this assessment are likely to be relevant to other threatened wader and migratory species (Faaborg et al. 2010a,b, Galbraith et al. 2014).

We undertook a systematic collation of expert opinion, a process increasingly used to inform ecological analyses and conservation decision-making ( $\mathrm{O}^{\prime}$ Neill et al. 2008, Kuhnert et al. 2010, Sutherland et al. 2012). Whilst threat assessments have previously been conducted for some flyways and regional Numeniini populations (e.g. Boere et al. 2006, Gill et al. 2007, Conklin et al. 2014, Hua et al. 2015), we have extended these approaches to produce a global assessment for the group. Specifically, we combined questionnaire responses from a wide-range of international experts with a subsequent workshop discussion including representatives from five continents, to identify: (I) key threats acting upon the Numeniini tribe as a whole; (2) how these threats vary between biogeographic populations and flyways; (3) critical knowledge gaps and priorities for future research; and (4) priority conservation actions. 
Table 1. Populations used as the basis for this analysis, based upon Wetlands International (2012).

\begin{tabular}{|c|c|c|c|c|}
\hline $\begin{array}{l}\text { Population } \\
\text { no. }\end{array}$ & Taxon & $\begin{array}{l}\text { Population name / } \\
\text { distribution }\end{array}$ & $\begin{array}{l}\text { IUCN status } \\
\text { of species }\end{array}$ & Flyway \\
\hline 1 & $\begin{array}{l}\text { Upland Sandpiper } \\
\text { Bartramia longicauda }\end{array}$ & Americas & Least Concern & Central Americas \\
\hline 2 & $\begin{array}{l}\text { Bristle-thighed Curlew } \\
\text { Numenius tahitiensis }\end{array}$ & W Alaska (breeding) & Vulnerable & Pacific Americas \\
\hline 3 & $\begin{array}{l}\text { Whimbrel Numenius } \\
\text { phaeopus hudsonicus }\end{array}$ & hudsonicus & Least Concern & Atlantic Americas \\
\hline 4 & $\begin{array}{l}\text { Whimbrel Numenius } \\
\text { phaeopus hudsonicus }\end{array}$ & rufiventris & & Pacific Americas \\
\hline 5 & $\begin{array}{l}\text { Whimbrel Numenius } \\
\text { phaeopus alboaxillaris }\end{array}$ & $\begin{array}{l}\text { alboaxillaris, } \\
\text { South-west Asia/ } \\
\text { Eastern Africa }\end{array}$ & & Central Asian \\
\hline 6 & $\begin{array}{l}\text { Whimbrel Numenius } \\
\text { phaeopus islandicus }\end{array}$ & $\begin{array}{l}\text { islandicus, Iceland } \\
\text { Faeroes and Scotland/ } \\
\text { West Africa }\end{array}$ & & East Atlantic \\
\hline 7 & $\begin{array}{l}\text { Whimbrel Numenius } \\
\text { phaeopus phaeopus }\end{array}$ & $\begin{array}{l}\text { phaeopus, Northern } \\
\text { Europe/West Africa }\end{array}$ & & East Atlantic \\
\hline 8 & $\begin{array}{l}\text { Whimbrel Numenius } \\
\text { phaeopus phaeopus }\end{array}$ & $\begin{array}{l}\text { phaeopus, West } \\
\text { Siberia/Southern } \\
\text { and Eastern Africa }\end{array}$ & & Black Sea \\
\hline 9 & $\begin{array}{l}\text { Whimbrel Numenius } \\
\text { phaeopus rogachevae }\end{array}$ & $\begin{array}{l}\text { Not listed in Wetlands } \\
\text { International (2012) }\end{array}$ & & Unknown \\
\hline 10 & $\begin{array}{l}\text { Whimbrel Numenius } \\
\text { phaeopus variegatus }\end{array}$ & $\begin{array}{l}\text { variegatus, S Asia } \\
\text { (non-breeding) }\end{array}$ & & Central Asian \\
\hline 11 & $\begin{array}{l}\text { Whimbrel Numenius } \\
\text { phaeopus variegatus }\end{array}$ & $\begin{array}{l}\text { variegatus, E and SE } \\
\quad \text { Asia (non-breeding) }\end{array}$ & & EAAF \\
\hline 12 & $\begin{array}{l}\text { Little Curlew Numenius } \\
\text { minutus }\end{array}$ & $\begin{array}{l}\text { Northern Siberia } \\
\text { (breeding) }\end{array}$ & Least Concern & EAAF \\
\hline 13 & $\begin{array}{l}\text { Eskimo Curlew Numenius } \\
\text { borealis }\end{array}$ & $\begin{array}{l}\text { Northern Canada } \\
\text { (breeding) }\end{array}$ & $\begin{array}{l}\text { Critically } \\
\text { Endangered } \\
\text { (Possibly } \\
\text { Extinct) }\end{array}$ & $\begin{array}{r}\text { Atlantic Americas / } \\
\text { Central Americas }\end{array}$ \\
\hline 14 & $\begin{array}{l}\text { Slender-billed Curlew } \\
\text { Numenius tenuirostris }\end{array}$ & $\begin{array}{l}\text { Central Siberia/ } \\
\text { Mediterranean } \\
\text { and SW Asia }\end{array}$ & $\begin{array}{l}\text { Critically } \\
\text { Endangered }\end{array}$ & Black Sea \\
\hline 15 & $\begin{array}{l}\text { Long-billed Curlew } \\
\text { Numenius americanus }\end{array}$ & americanus / parvus ${ }^{1}$ & Least Concern & Central Americas \\
\hline 16 & $\begin{array}{l}\text { Eurasian Curlew Numenius } \\
\text { arquata arquata }\end{array}$ & $\begin{array}{l}\text { arquata, Europe/ } \\
\text { Europe North and } \\
\text { West Africa }\end{array}$ & $\begin{array}{l}\text { Near } \\
\text { Threatened }\end{array}$ & East Atlantic \\
\hline 17 & $\begin{array}{l}\text { Eurasian Curlew Numenius } \\
\text { arquata orientalis }\end{array}$ & $\begin{array}{l}\text { orientalis, Western } \\
\text { Siberia/SW Asia } \\
\text { E and S Africa }\end{array}$ & & West Asian \\
\hline 18 & $\begin{array}{l}\text { Eurasian Curlew Numenius } \\
\text { arquata orientalis }\end{array}$ & $\begin{array}{l}\text { orientalis, S Asia } \\
\text { (non-breeding) }\end{array}$ & & Central Asian \\
\hline 19 & $\begin{array}{l}\text { Eurasian Curlew Numenius } \\
\text { arquata orientalis }\end{array}$ & $\begin{array}{l}\text { orientalis, E and SE } \\
\text { Asia (non-breeding) }\end{array}$ & & EAAF \\
\hline 20 & $\begin{array}{l}\text { Eurasian Curlew Numenius } \\
\text { arquata suschkini }\end{array}$ & $\begin{array}{l}\text { suschkini, South-east } \\
\text { Europe and South- } \\
\text { west Asia (breeding) }\end{array}$ & & West Asian \\
\hline 21 & $\begin{array}{l}\text { Far Eastern Curlew Numenius } \\
\text { madagascariensis }\end{array}$ & C and E Asia (breeding) & Vulnerable & EAAF \\
\hline
\end{tabular}


Table 1. Continued.

\begin{tabular}{|c|c|c|c|c|}
\hline $\begin{array}{l}\text { Population } \\
\text { no. }\end{array}$ & Taxon & $\begin{array}{l}\text { Population name / } \\
\text { distribution }\end{array}$ & $\begin{array}{l}\text { IUCN status } \\
\text { of species }\end{array}$ & Flyway \\
\hline 22 & $\begin{array}{l}\text { Bar-tailed Godwit Limosa } \\
\text { lapponica baueri }\end{array}$ & baueri & $\begin{array}{l}\text { Near } \\
\text { Threatened }\end{array}$ & EAAF \\
\hline 23 & $\begin{array}{l}\text { Bar-tailed Godwit Limosa } \\
\text { lapponica lapponica }\end{array}$ & $\begin{array}{l}\text { lapponica, Northern } \\
\text { Europe/Western } \\
\text { Europe }\end{array}$ & & East Atlantic \\
\hline 24 & $\begin{array}{c}\text { Bar-tailed Godwit Limosa } \\
\text { lapponica taymyrensis }\end{array}$ & $\begin{array}{l}\text { taymyrensis, Western } \\
\text { Siberia/West and } \\
\text { South-west Africa }\end{array}$ & & West Asian \\
\hline 25 & $\begin{array}{c}\text { Bar-tailed Godwit Limosa } \\
\text { lapponica taymyrensis }\end{array}$ & $\begin{array}{l}\text { taymyrensis, Central } \\
\text { Siberia/South and } \\
\text { SW Asia and Eastern } \\
\text { Africa }\end{array}$ & & Black Sea \\
\hline 26 & $\begin{array}{l}\text { Bar-tailed Godwit Limosa } \\
\text { lapponica menzbieri and } \\
\text { Limosa lapponica } \\
\text { anadyrensis }\end{array}$ & $\begin{array}{l}\text { menzbieri (and } \\
\text { anadyrensis) }\end{array}$ & & EAAF \\
\hline 27 & $\begin{array}{l}\text { Marbled godwit Limosa } \\
\text { fedoa fedoa }\end{array}$ & $\begin{array}{l}\text { fedoa, SC Canada and } \\
\text { NC USA (breeding) }\end{array}$ & $\begin{array}{l}\text { Least } \\
\text { Concern }\end{array}$ & $\begin{array}{l}\text { Pacific Americas / } \\
\text { Central Americas }\end{array}$ \\
\hline 28 & $\begin{array}{l}\text { Marbled godwit Limosa } \\
\text { fedoa fedoa }\end{array}$ & $\begin{array}{l}\text { fedoa, James Bay } \\
\text { (breeding) }\end{array}$ & & Atlantic Americas \\
\hline 29 & $\begin{array}{l}\text { Marbled Godwit Limosa } \\
\text { fedoa beringiae }\end{array}$ & beringiae & & Pacific Americas \\
\hline 30 & $\begin{array}{l}\text { Hudsonian Godwit Limosa } \\
\text { haemastica }\end{array}$ & Alaska (breeding) & $\begin{array}{l}\text { Least } \\
\text { Concern }\end{array}$ & Atlantic Americas \\
\hline 31 & $\begin{array}{l}\text { Hudsonian Godwit Limosa } \\
\text { haemastica }\end{array}$ & Hudson Bay (breeding) & & $\begin{array}{l}\text { Atlantic Americas / } \\
\text { Central Americas }\end{array}$ \\
\hline 32 & $\begin{array}{l}\text { Black-tailed Godwit Limosa } \\
\text { limosa limosa }\end{array}$ & $\begin{array}{l}\text { limosa, Western } \\
\text { Europe/NW and } \\
\text { West Africa }\end{array}$ & $\begin{array}{l}\text { Near } \\
\text { Threatened }\end{array}$ & East Atlantic \\
\hline 33 & $\begin{array}{l}\text { Black-tailed Godwit Limosa } \\
\text { limosa limosa }\end{array}$ & $\begin{array}{l}\text { limosa, Eastern } \\
\text { Europe/Central } \\
\text { and Eastern Africa }\end{array}$ & & Black Sea \\
\hline 34 & $\begin{array}{l}\text { Black-tailed Godwit Limosa } \\
\text { limosa limosa }\end{array}$ & $\begin{array}{l}\text { limosa, West-central } \\
\text { Asia/SW Asia and } \\
\text { Eastern Africa }\end{array}$ & & West Asian \\
\hline 35 & $\begin{array}{l}\text { Black-tailed Godwit Limosa } \\
\text { limosa limosa }\end{array}$ & $\begin{array}{l}\text { limosa, S Asia } \\
\quad \text { (non-breeding) }\end{array}$ & & Central Asian \\
\hline 36 & $\begin{array}{l}\text { Black-tailed Godwit Limosa } \\
\text { limosa islandica }\end{array}$ & $\begin{array}{l}\text { islandica, Iceland/ } \\
\text { Western Europe }\end{array}$ & & East Atlantic \\
\hline 37 & $\begin{array}{l}\text { Black-tailed Godwit Limosa } \\
\text { limosa melanuroides }\end{array}$ & melanuroides & & EAAF \\
\hline
\end{tabular}

${ }^{1}$ Although previously considered as separate subspecies or populations (Wetlands International 2012), for the purposes of this review, we considered that any differences were insufficient for them to be assessed other than as a single population.

\section{Methods}

The Numeniini tribe is not taxonomically monophyletic, but contains ecologically similar species from two clades likely to face similar threats, and hence are considered together. The Numenius clade is basal to all other Scolopacidae (except Jacanas and allies), while Limosa is a younger group and basal to the sandpipers and allies (Gibson and Baker 2012). Although there remains some 
uncertainty over the taxonomic identity of some populations and subspecies, we used the most recent research and/or expert opinion to identify a total of 37 taxonomically distinct subspecies and biogeographic populations for assessment as part of our review (Table 1 ).

Assessments were conducted for each population as follows. First, a questionnaire was devised and circulated electronically to experts from around the world from July to September 2013, requesting information about the threats acting upon different populations. Threats were listed on the questionnaire in accordance with the IUCN-CMP Unified Classification of Direct Threats Version 3.2., and based on Salafsky et al. (2008), adopting a spread of first- to third-order threats as appropriate for the species group (Table 2). This ensured that all contributors considered threats in a consistent manner and that consideration was given to all potential threats. Experts were asked to separately score changes in both the scale and intensity of the threats over the last 25 years on a five point scale $(-2=$ strong decrease, $-I=$ decrease, $O=$ no change, $I=$ increase, $2=$ strong increase), as well as the likelihood of each threat being linked to population change ( $\mathrm{o}=$ unlikely, $I=$ possibly, 2 = strongly $)$ and the evidence to support this assessment $(I=$ poor - based on expert opinion, 2 = moderate - based on correlative studies, 3 = good - based on experimental studies). Separate assessments were requested for the breeding and non-breeding stages of each population's annual cycle. In some instances where populations are dependent on more than one geographical location/region during the non-breeding period (including on migration), assessments were provided separately for each. In total, 115 assessments were received.

The second stage was to review and discuss these scores at a one-day workshop attended by over 50 experts from around the world at the International Wader Study Group's annual conference in Wilhelmshaven, Germany, on 30 September 2013. Prior to this event, the scores from the questionnaire were collated separately for breeding and non-breeding populations by JWPH, DJB and DJTD; where multiple responses were received for the same population, scores were averaged. At the workshop, the summarised population responses were presented and refined in plenary by one of three working groups focussed on populations confined to flyways in either the Americas; Europe, Africa and West Asia; or Asia and Oceania. In the few cases where populations spend part of their life cycles across more than one of the designated groups (e.g. Bar-tailed Godwit Limosa lapponica baueri, which breeds in Alaska, overwinters in Australia and New Zealand, then stages for a month in the Yellow Sea) the assessments were refined by both relevant groups. Each group comprised 10-20 people with expertise in each region.

The focus of these working groups was to collate the threat scores for each breeding and non-breeding population separately. At this stage, the process was simplified so that scores were obtained for the change in the threat (combining estimates of change in both scale and intensity, which respondents to the questionnaires had difficulty separating), the impact of that change upon the population of interest $(-2=$ strong negative impact, $-1=$ likely negative impact, $\mathrm{o}=$ no impact, $1=$ likely positive impact, 2 = strong positive impact), and the evidence to support the impact of a threat. Scores were subsequently circulated to additional experts who were unable to attend the workshop to address any gaps and uncertainties identified. This resulted in a final set of scores for the CHANGE in the threat $(-2=$ strong decrease, $-1=$ decrease, $\mathrm{O}=$ no change, $1=$ increase, $2=$ strong increase), IMPACT of the change in the threat $(-2=$ strong negative impact, $-1=$ likely negative impact, $\mathrm{O}=$ no impact, $\mathrm{I}=$ likely positive impact, $2=$ strong positive impact) and EVIDENCE to support the impact of the threat $(1=$ poor based on expert opinion, $2=$ moderate based on correlative studies, 3 = good based on experimental studies) for each population and stage in the life cycle (breeding and non-breeding). Populations were assigned to one of the world's nine major flyways (Figure 1 ), except for a small number of populations that span two flyways during migration, in which case two non-breeding scores were produced. We were unable to make any assessments with respect to non-breeding populations in the Central Asian Flyway; a significant knowledge gap requiring further attention (although see Szabo and Mundkur in press). When we summarised the results by flyway and life cycle stage, we used our collective knowledge to identify instances where threats were known to either primarily impact final non-breeding areas, where birds spend the majority of the Northern Hemisphere winter, or stop-over and staging locations during migration. 
Table 2. Classification of threats and their definition used in the assessment, adapted from Salafsky et al. (2008).

\begin{tabular}{|c|c|c|}
\hline $\begin{array}{l}\text { Adapted Salafsky et al. (2008) } \\
\text { classification }\end{array}$ & Simplified title & Definition \\
\hline 1. residential and commercial development & Development & Threats from human settlements or other non-agricultural land uses \\
\hline 2.1. annual and perennial non-timber crops & Non-timber crops & Threats from crops planted for food, fodder, fibre, fuel, or other uses \\
\hline 2.2. wood and pulp plantations & Plantations & Threats from stands of trees planted for timber or fibre outside of natural forests \\
\hline 2.3. livestock farming and ranching & Livestock & $\begin{array}{l}\text { Threats from domestic terrestrial animals raised in one location on farmed or nonlocal resources } \\
\text { (farming); or domestic or semi-domesticated animals allowed to roam in the wild and supported } \\
\text { by natural habitats (ranching) }\end{array}$ \\
\hline 2.4. marine and freshwater aquaculture & Aquaculture & $\begin{array}{l}\text { Threats from aquatic animals raised in one location on farmed or nonlocal resources; also hatchery } \\
\text { fish allowed to roam in the wild }\end{array}$ \\
\hline $\begin{array}{l}\text { 3.1, 3.2. oil and gas drilling, mining and } \\
\text { quarrying }\end{array}$ & Mining & Threats from exploring, developing and producing non-biological resources, excluding renewables \\
\hline 3.3. renewable energy development & Renewables & Threats from exploring, developing, and producing renewable energy \\
\hline 4. transportation and service corridors & Transport & $\begin{array}{l}\text { Threats from long, narrow transport corridors and the vehicles that use them including associated } \\
\text { wildlife mortality }\end{array}$ \\
\hline 5.1. hunting and collecting of target species & Hunting & $\begin{array}{l}\text { Threats from killing or trapping terrestrial wild animals or animal products for commercial, } \\
\text { recreation, subsistence, research or cultural purposes, or for control/persecution reasons; } \\
\text { includes accidental mortality/by-catch }\end{array}$ \\
\hline $\begin{array}{l}\text { 5.1.a management to support the hunting } \\
\text { and collecting of target species }\end{array}$ & $\begin{array}{l}\text { Hunting } \\
\text { side-effects (HSE) }\end{array}$ & $\begin{array}{l}\text { Side-effects of killing or trapping terrestrial wild animals, including the impacts of management } \\
\text { to support hunting, such as predator control. }\end{array}$ \\
\hline 5.4. fishing and harvesting aquatic resources & Fishing & $\begin{array}{l}\text { Threats from harvesting aquatic wild animals or plants for commercial, recreation, subsistence, } \\
\text { research, or cultural purposes, or for control/persecution reasons; includes accidental mortality/ } \\
\text { by-catch }\end{array}$ \\
\hline 6. human intrusions and disturbance & Disturbance & $\begin{array}{l}\text { Threats from human activities associated with non-consumptive uses of biological resources that } \\
\text { alter, destroy and disturb habitats and species }{ }^{1}\end{array}$ \\
\hline 7.1. fire and fire suppression & Fire & $\begin{array}{l}\text { Impacts of suppression or increase in fire frequency and/or intensity outside of its natural range } \\
\text { of variation }\end{array}$ \\
\hline 7.2.1. dams and water management & Dams & $\begin{array}{l}\text { Impacts of slowing water flow through dams and other water managements outside of natural } \\
\text { range of variation, to raise water levels }\end{array}$ \\
\hline 7.2.a. drainage & Drainage & $\begin{array}{l}\text { Impacts of increasing flow of water from wetland or waterlogged terrestrial areas through } \\
\text { drainage, to reduce water levels. }\end{array}$ \\
\hline 8.1. invasive non-native/alien species & $\begin{array}{l}\text { Problematic invasive } \\
\text { species (PIS) }\end{array}$ & $\begin{array}{l}\text { Threats from harmful plants and animals not originally found within the ecosystem(s) in } \\
\text { question and directly or indirectly introduced and spread into it by human activities }\end{array}$ \\
\hline
\end{tabular}


Table 2. Continued.

\begin{tabular}{lll}
\hline $\begin{array}{l}\text { Adapted Salafsky et al. (2008) } \\
\text { classification }\end{array}$ & Simplified title & Definition \\
\hline 8.1.a. disease & Disease & $\begin{array}{c}\text { Threats from pathogens/microbes that have or are predicted to have harmful effects on } \\
\text { biodiversity following their introduction, spread and/or increase in abundance }\end{array}$ \\
8.2. problematic native species & $\begin{array}{c}\text { Threats from harmful plants, animals, or pathogens and other microbes that are originally found } \\
\text { within the ecosystem(s) in question, but have become "out of balance" or "released" directly or } \\
\text { indirectly due to human activities }\end{array}$ \\
species (PNS) & $\begin{array}{c}\text { Threats from introduction of exotic and/or excess materials or energy from point and } \\
\text { nonpoint sources }\end{array}$ \\
T1. climate change and severe weather & Climate change & $\begin{array}{c}\text { Theats from long-term climatic changes and other severe climatic or weather events outside the } \\
\text { natural range of variation }\end{array}$ \\
\hline
\end{tabular}

${ }^{1}$ Whilst this definition was used in the questionnaire, it was highlighted in our workshop that some could have been interpreted this to have included the effects of widespread habitat destruction. As a result, we ensured that our final workshop scoring was focussed specifically on the direct effects of human disturbance upon individuals, rather than effects of habitat destruction. 


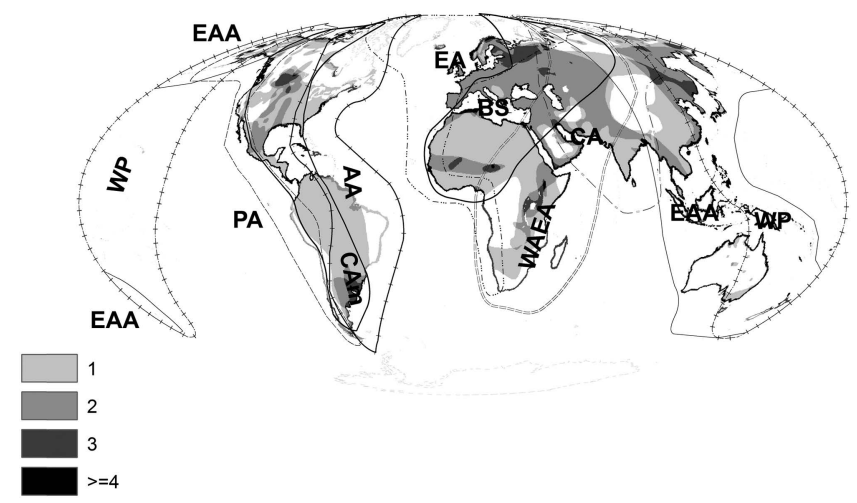

Figure 1. Global flyways (Wetlands International 2014) overlaid on Numeniini species richness (numbers in legend) derived from BirdLife International range polygons. White areas are outside the global range of Numeniini species. Flyways are abbreviated as follows (PA, Pacific Americas; CAm, Central Americas; AA, Atlantic Americas; EA, East Atlantic; BS, Black Sea; WAEA, West Asian; CA, Central Asian; EAA, East Asian-Australasian; WP, West Pacific).

\section{Analysis}

We first examined global patterns across all species and populations, to show how CHANGE, IMPACT and EVIDENCE scores, as response variables in separate models, varied between threats. Second, we tested evidence for consistent variation in threats between breeding and non-breeding populations, and among flyways. Third, we examined the extent to which CHANGE in, and IMPACT of, threats showed consistent seasonal variation across flyways, by testing the significance of the interaction between season and flyway.

We analysed scores for CHANGE, IMPACT and EVIDENCE using a binomial structure, which allowed estimates to be constrained by the upper and lower bounds of the scores provided. To facilitate this, we rescaled our CHANGE and IMPACT scores to vary from o to 8 (accounting for the small number of half-scores provided by experts), with o equivalent to $-2,4$ to o, and 8 to +2 , and transformed our EVIDENCE scores so that they varied from o to 2. Each score was then modelled as a proportion of the maximum using a binomial error structure and logit link function. At the end of this process, modelled probabilities were back-transformed to reflect their original values. We used Generalised Linear Mixed Models (GLMMs) with species as a random effect to reflect the potential non-independence of scores from different populations of the same species. However, in the third analysis of flyway* season interactions, estimates of covariance attributed to random effects were very small, due to the lack of replication within combinations of flyway and season. As a result, the models failed to converge as GLMMS, so we instead used Generalised Linear Models (GLMs) without any random effects. All analysis was conducted in SAS v.9.4.

\section{Results}

\section{Global patterns}

There was significant variation in the degree of change in threats across all populations (CHANGE, $\mathrm{F}_{19,1280}=14.64, P<0.0001$; Figure 2a). Most threats were regarded as showing statistically significant increases in scale and/or intensity, with the exceptions being non-timber crops, livestock, hunting, hunting side-effects and disease. Across all populations, the impact of these threats also varied significantly (IMPACT, $\mathrm{F}_{19,1280}=5.06, P<0.0001$; Figure $2 \mathrm{~b}$ ), with strong negative 


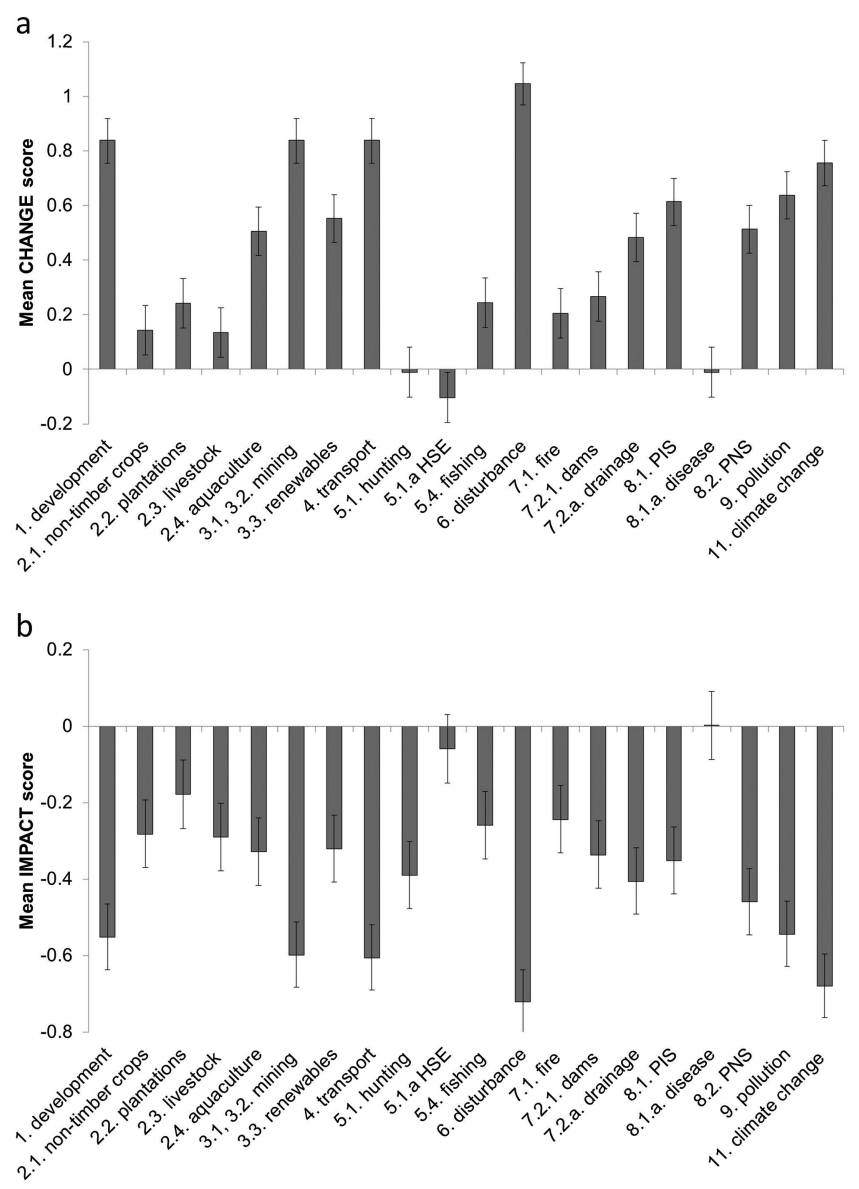

Figure 2. Mean ( \pm SE) CHANGE (a) and IMPACT (b) scores across all populations. Scores represent least-square mean estimates from a GLMM model with species as a random effect. HSE - Hunting side-effects, PIS - Problematic invasive species, PNS - Problematic native species

(IMPACT < -0.5) scores for development, mining, transport, disturbance, pollution and climate change. At this level, there was a strong negative correlation between the change associated with threats, and the impacts of those threats (IMPACT versus CHANGE, $\mathrm{r}=-0.83, n=20, P<0.0001$ ), suggesting that threats which were scored as increasing most in magnitude were also scored as having the greatest impact. There were no overall significant differences in the degree of evidence attributed to threats $\left(\mathrm{F}_{1,19}=0.62, P=0.78\right)$. In most cases, the amount of evidence scored was poor (mean EVID scores range from 1.33 to 1.47 across different threats), and therefore this assessment is largely based upon expert opinion rather than published studies (see Appendix $\mathrm{S}_{I}$ in the online supplementary material for exceptions).

\section{Variation between seasons}

The direction and severity of trends in threats varied significantly between breeding and nonbreeding seasons (CHANGE, threat ${ }^{*}$ season interaction, $\mathrm{F}_{19,1260}=6.46, P<0.0001$ ). Development, aquaculture, renewables, transport, fishing, disturbance, dams, drainage, problematic invasive 
species and pollution were regarded as having increased significantly more in non-breeding than breeding areas (Figure 3a). Conversely, threats of hunting and problematic native species increased on the breeding grounds by significantly more than non-breeding areas, although breeding season trends for hunting did not differ significantly from zero (Figure $3 \mathrm{a}$ ). The effect of these threats upon populations also differed significantly with season (IMPACT, $\mathrm{F}_{19,1260}=3.48, \mathrm{P}<0.0001$ ). The threats most strongly regarded as impacting breeding populations (mean IMPACT score $<-0.5$ ) were mining, disturbance, problematic native species and climate change. A greater number of strong impacts were identified on the non-breeding grounds (Figure $3 \mathrm{~b}$ ): development, aquaculture, mining, transport, disturbance, problematic invasive species, pollution and climate change.

\section{Variation between flyways}

Scored trends in threats varied among flyways (CHANGE, threat ${ }^{*}$ flyway interaction, $\mathrm{F}_{152,1140}=$ $1.68, P<0.0001$ ) and did not vary consistently with season among flyways (threat ${ }^{*}$ season ${ }^{*}$ flyway
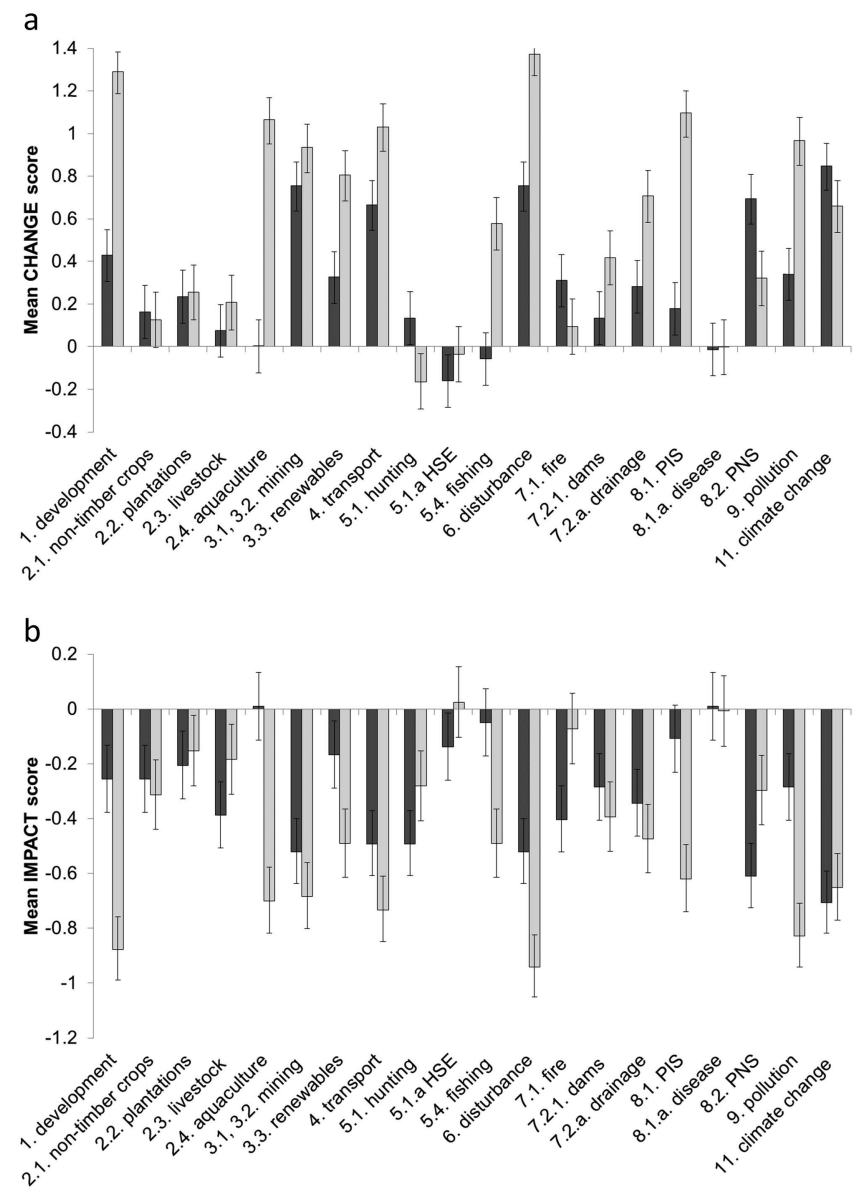

Figure 3. Mean ( \pm SE) CHANGE (a) and IMPACT (b) scores differ between breeding (dark grey) and non-breeding (light grey) areas. Estimates are from least-square means with species as a random effect. HSE - Hunting side-effects, PIS - Problematic invasive species, PNS - Problematic native species 
interaction, $\left.\mathrm{F}_{140,980}=1.34, P=0.0082\right)$. Threats were not scored as having impacts that differed among flyways (IMPACT threat ${ }^{*}$ flyway interaction, $F_{152,1138}=1.03, P=0.40$ ), or with strong differences in the seasonal effects among flyways (threat* ${ }^{*}$ season*flyway interaction, $F_{140,980}=$ 1.13, $P=0.15)$. As the CHANGE scores varied among flyways, and to reflect specific differences between them, we summarised the main threats, and their impacts on populations, separately by flyway and season. This enabled us to describe the differences that occurred, and demonstrate which threats were regarded as more important for particular flyways (Table 3). Severe threats were those whose IMPACT $<-0.5$, whilst moderate threats had a consistent negative impact, as shown by a score that differed significantly from zero. Threats with an impact score that did not differ significantly from zero were regarded as unimportant.

Breeding populations in the East Atlantic Flyway faced the greatest number of severe threats (seven); this was the only flyway where non-timber crops, plantations and dams threatened breeding populations. Species breeding in the Central Americas, Atlantic Americas and West Asian flyways were exposed to five severe threats (Table 3). Mining, hunting, disturbance, problematic native species and climate change were all regarded as severe threats across the breeding populations of at least three flyways.

Table 3. The mean CHANGE score (arrows), indicating changes in the scale and intensity of each threat (rows), and IMPACT score (shading), indicating the likely impact of that threat being linked to population change, separately for the breeding season and non-breeding periods. Diagonal arrows and amber cells (mid grey) indicate combinations with statistically significant CHANGE and IMPACT scores respectively, regarded as moderate. Up arrows and red (dark grey) cells indicate where CHANGE $>0.5$ or IMPACT $<-0.5$ respectively, and may therefore be regarded as severe. Green (light grey) cells and horizontal arrows indicate that IMPACT and CHANGE scores respectively did not differ significantly from zero. We were unable to make a non-breeding assessment for the Central Asian flyway. EAAF, East Asian - Australasian Flyway; PIS, problematic invasive species; PNS, problematic native species. Where we are aware of a clear separation in the non-breeding threats between migratory stop-over locations and final non-breeding locations, these are denoted by ${ }^{\mathrm{M}}$ and ${ }^{\mathrm{F}}$ respectively.

\begin{tabular}{|c|c|c|c|c|c|c|c|c|c|}
\hline Breeding & $\begin{array}{c}\text { Pacific } \\
\text { Americas }\end{array}$ & $\begin{array}{c}\text { Central } \\
\text { Americas }\end{array}$ & $\begin{array}{c}\text { Atlantic } \\
\text { Americas }\end{array}$ & East Atlantic & Black Sea & West Asian & Central Asian & EAAF & West Pacific \\
\hline Development & $\rightarrow$ & $\rightarrow$ & $\rightarrow$ & $\uparrow$ & $\rightarrow$ & $\rightarrow$ & $\rightarrow$ & $\rightarrow$ & $\rightarrow$ \\
\hline Non-timber crops & $\rightarrow$ & $\rightarrow$ & $\rightarrow$ & $\uparrow$ & $\rightarrow$ & $\rightarrow$ & $\rightarrow$ & $\rightarrow$ & $\rightarrow$ \\
\hline Plantations & $\rightarrow$ & $\rightarrow$ & $\rightarrow$ & $\uparrow$ & $\rightarrow$ & $\rightarrow$ & $\rightarrow$ & $\rightarrow$ & $\rightarrow$ \\
\hline Livestock & $\rightarrow$ & $\rightarrow$ & $\rightarrow$ & $\uparrow$ & $\rightarrow$ & $\rightarrow$ & $\rightarrow$ & $\rightarrow$ & $\rightarrow$ \\
\hline Aquaculture & $\rightarrow$ & $\rightarrow$ & $\rightarrow$ & $\rightarrow$ & $\rightarrow$ & $\rightarrow$ & $\rightarrow$ & $\rightarrow$ & $\rightarrow$ \\
\hline Mining & $\uparrow$ & $\uparrow$ & $\uparrow$ & $\rightarrow$ & $\rightarrow$ & $\rightarrow$ & $\rightarrow$ & $\rightarrow$ & $\pi$ \\
\hline Renewables & $\rightarrow$ & $\rightarrow$ & $\rightarrow$ & $\uparrow$ & $\rightarrow$ & $\rightarrow$ & $\rightarrow$ & $\rightarrow$ & $\rightarrow$ \\
\hline Transport & $\rightarrow$ & $\rightarrow$ & $\rightarrow$ & $\rightarrow$ & $\rightarrow$ & $\uparrow$ & $\uparrow$ & $\rightarrow$ & $\pi$ \\
\hline Hunting & $\rightarrow$ & $\rightarrow$ & $\rightarrow$ & $\rightarrow$ & $\rightarrow$ & $\uparrow$ & $\rightarrow$ & $\rightarrow$ & $\rightarrow$ \\
\hline Hunting side-effects & $\rightarrow$ & $\rightarrow$ & $\rightarrow$ & $\rightarrow$ & $\rightarrow$ & $\rightarrow$ & $\rightarrow$ & $\rightarrow$ & $\rightarrow$ \\
\hline Fishing & $\rightarrow$ & $\rightarrow$ & $\rightarrow$ & $\rightarrow$ & $\rightarrow$ & $\rightarrow$ & $\rightarrow$ & $\rightarrow$ & $\rightarrow$ \\
\hline Disturbance & $\rightarrow$ & $\uparrow$ & $\uparrow$ & $\rightarrow$ & $\rightarrow$ & $\uparrow$ & $\rightarrow$ & $\rightarrow$ & $\rightarrow$ \\
\hline Fire & $\rightarrow$ & $\rightarrow$ & $\rightarrow$ & $\rightarrow$ & $\rightarrow$ & $\uparrow$ & $\rightarrow$ & $\uparrow$ & $\rightarrow$ \\
\hline Dams & $\rightarrow$ & $\rightarrow$ & $\rightarrow$ & $\pi$ & $\rightarrow$ & $\rightarrow$ & $\rightarrow$ & $\rightarrow$ & $\rightarrow$ \\
\hline Drainage & $\rightarrow$ & $\pi$ & $\rightarrow$ & $\uparrow$ & $\rightarrow$ & $\rightarrow$ & $\rightarrow$ & $\rightarrow$ & $\rightarrow$ \\
\hline PIS & $\rightarrow$ & $\rightarrow$ & $\rightarrow$ & $\rightarrow$ & $\rightarrow$ & $\rightarrow$ & $\rightarrow$ & $\rightarrow$ & $\rightarrow$ \\
\hline Disease & $\rightarrow$ & $\rightarrow$ & $\rightarrow$ & $\rightarrow$ & $\rightarrow$ & $\rightarrow$ & $\rightarrow$ & $\rightarrow$ & $\rightarrow$ \\
\hline PNS & $\rightarrow$ & $\uparrow$ & $\uparrow$ & $\uparrow$ & $\rightarrow$ & $\rightarrow$ & $\rightarrow$ & $\rightarrow$ & $\rightarrow$ \\
\hline Pollution & $\rightarrow$ & $\rightarrow$ & $\rightarrow$ & $\rightarrow$ & $\rightarrow$ & $\uparrow$ & $\rightarrow$ & $\rightarrow$ & $\lambda$ \\
\hline Climate change & $\rightarrow$ & $\uparrow$ & $\uparrow$ & $\uparrow$ & $\rightarrow$ & $\rightarrow$ & $\rightarrow$ & $\rightarrow$ & $\rightarrow$ \\
\hline
\end{tabular}


Table 3. Continued.

\begin{tabular}{|c|c|c|c|c|c|c|c|c|c|}
\hline Non-breeding & $\begin{array}{c}\text { Pacific } \\
\text { Americas }\end{array}$ & $\begin{array}{c}\text { Central } \\
\text { Americas }\end{array}$ & $\begin{array}{l}\text { Atlantic } \\
\text { Americas }\end{array}$ & East Atlantic & Black Sea & West Asian & Central Asian & EAAF $^{1}$ & West Pacific \\
\hline Development & $\uparrow$ & $\uparrow$ & $\pi$ & $\rightarrow$ & $\rightarrow$ & $\uparrow^{M}$ & & $\uparrow^{m}$ & $\pi$ \\
\hline Non-timber crops & $\rightarrow$ & $\rightarrow$ & $\rightarrow$ & $\uparrow$ & $\rightarrow$ & $\rightarrow$ & & $\rightarrow$ & $\rightarrow$ \\
\hline Plantations & $\rightarrow$ & $\rightarrow$ & $\rightarrow$ & $\rightarrow$ & $\rightarrow$ & $\rightarrow$ & & $\rightarrow$ & $\pi$ \\
\hline Livestock & $\rightarrow$ & $\rightarrow$ & $\rightarrow$ & $\rightarrow$ & $\rightarrow$ & $\rightarrow$ & & $\rightarrow$ & $\pi$ \\
\hline Aquaculture & $\rightarrow$ & $\rightarrow$ & $\pi$ & $\uparrow$ & $\rightarrow$ & $\rightarrow$ & & $\uparrow$ & $\rightarrow$ \\
\hline Mining & $\rightarrow$ & $\uparrow^{M}$ & $\rightarrow$ & $\rightarrow$ & $\rightarrow$ & $\uparrow$ & & $\uparrow^{M}$ & $\rightarrow$ \\
\hline Renewables & $\lambda^{m}$ & $\rightarrow$ & $\rightarrow$ & $\uparrow$ & $\rightarrow$ & $\rightarrow$ & & $\uparrow^{M}$ & $\pi$ \\
\hline Transport & $\uparrow$ & $\uparrow$ & $\uparrow$ & $\uparrow$ & $\rightarrow$ & $\rightarrow$ & & $\uparrow^{M}$ & $\pi$ \\
\hline Hunting & $\rightarrow^{M}$ & $\rightarrow$ & $\rightarrow^{M}$ & $\rightarrow$ & $\rightarrow$ & $\rightarrow$ & & $\rightarrow$ & $\pi$ \\
\hline Hunting side-effects & $\rightarrow$ & $\rightarrow$ & $\rightarrow$ & $\rightarrow$ & $\rightarrow$ & $\rightarrow$ & & $\rightarrow$ & $\rightarrow$ \\
\hline Fishing & $\rightarrow$ & $\rightarrow$ & $\uparrow$ & $\uparrow$ & $\rightarrow$ & $\rightarrow$ & & $\uparrow$ & $\rightarrow$ \\
\hline Disturbance & $\uparrow$ & $\uparrow^{F}$ & $\pi$ & $\uparrow$ & $\uparrow$ & $\uparrow$ & & $\uparrow$ & $\pi$ \\
\hline Fire & $\rightarrow$ & $\rightarrow$ & $\rightarrow$ & $\rightarrow$ & $\rightarrow$ & $\rightarrow$ & & $\rightarrow$ & $\rightarrow$ \\
\hline Dams & $\rightarrow$ & $\rightarrow$ & $\rightarrow$ & $\rightarrow$ & $\rightarrow$ & $\rightarrow$ & & $\uparrow^{M}$ & $\rightarrow$ \\
\hline Drainage & $\rightarrow$ & $\uparrow$ & $\rightarrow$ & $\uparrow$ & $\rightarrow$ & $\rightarrow$ & & $\uparrow^{M}$ & $\rightarrow$ \\
\hline PIS & $\uparrow^{F}$ & $\rightarrow$ & $\uparrow$ & $\rightarrow$ & $\rightarrow$ & $\rightarrow$ & & $\uparrow^{M}$ & $\pi$ \\
\hline Disease & $\rightarrow$ & $\rightarrow$ & $\rightarrow$ & $\rightarrow$ & $\rightarrow$ & $\rightarrow$ & & $\rightarrow$ & $\rightarrow$ \\
\hline PNS & $\pi$ & $\pi$ & $\rightarrow$ & $\rightarrow$ & $\rightarrow$ & $\rightarrow$ & & $\rightarrow$ & $\rightarrow$ \\
\hline Pollution & $\pi$ & $\uparrow$ & $\uparrow$ & $\rightarrow$ & $\rightarrow$ & $\rightarrow$ & & $\uparrow$ & $\pi$ \\
\hline Climate change & $\pi^{F}$ & $\uparrow^{M}$ & $\rightarrow$ & $\uparrow$ & $\rightarrow$ & $\rightarrow$ & & $\rightarrow$ & $\pi$ \\
\hline
\end{tabular}

${ }^{1}$ Threats primarily affecting migratory stop-over locations in East and South-east Asia and are coded as ${ }^{\mathrm{M}}$, but may also affect populations for which these locations are also final non-breeding locations. The majority of populations overwinter in Australia and New Zealand, where they face fewer threats.

More severe threats were assigned to non-breeding populations than breeding populations. Over half of the threats (II) were scored as severe across the East Asian-Australasian Flyway (EAAF), whilst populations using the Central Americas, Atlantic Americas and East Atlantic flyways were also scored as being exposed to a large number of threats (7-8). Development, aquaculture, mining, transport, fishing, disturbance, problematic invasive species and pollution were severe threats across at least five flyways. Severe negative impacts of disturbance were almost ubiquitous for non-breeding populations. Threats across the EAAF were thought to primarily affect migratory stop-over locations in East and South-East Asia, whilst the distribution of threats across other flyways was more mixed (Table 3 ).

\section{Discussion}

Over half of the species in the Numeniini tribe have been classified as threatened or Near Threatened, with two possibly extinct (BirdLife International 2015b), and a number of biogeographic populations and subspecies are considered highly threatened (Brown et al. 2014). Previous work has shown that global extinction risk in birds is greatest in large species with slow generation time (Gaston and Blackburn 1995, Owens and Bennett 2000). More detailed analyses of population trends in well-studied European populations suggests that habitat-specialists, ground-nesting species and long-distance migrants are among the species with the most negative population trends (Julliard et al. 2003, Thaxter et al. 2010, Sullivan et al. 2015). Numeniini exhibit all of these traits: many are relatively large-bodied with delayed maturity and low fecundity; specialists of open, often semi-natural habitats during the breeding season and coastal habitats at other 
times; ground-nesting; and highly migratory. These traits must at least partially account for why so many Numeniini species are currently of conservation concern.

The small size and fragmentation of some subspecies and populations (Brown et al. 2014) also adds to their threat status; some populations are more threatened than the corresponding species. Furthermore, threats may vary widely among different populations of the same species, but overlap with other populations or subspecies sharing a migratory flyway (Table 3). For example, orientalis Eurasian Curlew populations and variegatus Whimbrel populations using the EAAF are particularly threatened by coastal development, whilst arquata Eurasian Curlew and phaeopus Whimbrel are less affected. Given that populations of some Numeniini species occupy a wide range of geographical locations, flyways and migratory strategies, conservation efforts should be targeted at improving the status of each separate population, rather than simply considering the overall status of the species. This strategy would also be resilient to any future changes in Numeniini taxonomy that may split some of the current subspecies and populations into separate species.

In an effort to identify key threats and knowledge gaps pertaining to the conservation of these species, we created an expert-based assessment that collated and scored threats acting upon individual species and populations across flyways. Globally, this assessment identified residential and commercial development, mining, transport, disturbance, pollution and climate change as having the greatest impacts overall, although the primary threats differed considerably between breeding and non-breeding areas, and among flyways. These seasonal differences likely relate to the long distances between breeding and non-breeding areas, or differences in the habitat associations of Numeniini during the breeding and non-breeding seasons. Many Numeniini breed across large areas of less-intensively managed wetland, upland or tundra habitats, while they often spend the non-breeding period concentrated in coastal areas in temperate and tropical zones that are subject to very different pressures. Some non-breeding threats also differed between migratory stop-over locations and final non-breeding locations, largely in relation to the amount of geographical separation between them. This was most apparent within the EAAF flyway where many populations winter in Australia and New Zealand but stage in the Yellow Sea during their spring migration (e.g. Little Curlew Numenius minutus, Far Eastern Curlew, baueri Bar-tailed Godwit), whilst in other flyways, such as the East Atlantic, staging and non-breeding locations tended to be less discrete (Table 1 ).

Populations occupying American and Afro-Eurasia flyways are threatened by a mix of breeding and non-breeding season threats which are likely to affect both breeding success and mortality. Populations using the EAAF and West Pacific flyways are threatened largely by non-breeding threats most likely to alter mortality, although these pressures may also influence breeding success through carry-over effects (Gunnarsson et al. 2005, Alves et al. 2013 but see also Senner et al. 2014, 2015). Given that Numeniini species generally have delayed maturity, high survival and low fecundity (Piersma and Baker 2000), populations are likely most sensitive to variation in mortality rates (Sæther and Bakke 2000), although they may also be sensitive to reductions in fecundity that limit their ability to recover from mortality-driven declines (Robinson et al. 2014). To illustrate this, the $46 \%$ decline in Eurasian Curlew populations in the UK (Harris et al. 2015) has occurred despite high and increased adult survival rates resulting from a cessation of hunting (Taylor and Dodd 2013). Similarly, the ongoing decline of the continental Black-tailed Godwit populations is due to recruitment failure as a consequence of the intensification of grassland management leading to increased egg losses (Kentie et al. 2015) and chick mortality (Kentie et al. 2013).

Whilst important differences in threats between flyways were identified, a greater number of similarities were apparent, which are discussed below. When doing so, we recognize that the evidence base underpinning this expert assessment is limited. For instance, despite considerable effort to include participants from across the globe, we were unable to report on threats to nonbreeding populations using the Central Asian flyway (where declines of Numeniini and other waders are thought to be occurring due to rapid coastal development, e.g. Balachandran 2006, Szabo and Mundkur in press), and we received greater input for some flyways (e.g. the three Americas flyways and the East Atlantic flyway) than others. We cannot therefore exclude the possibility that some of the geographic variation in our assessment may reflect limitations in our 
own knowledge. As a result, we have also provided a post-hoc assessment of the peer-reviewed scientific evidence in support of the threats identified. This has helped us to identify subsequent research priorities.

Many of the published studies examined only individual threats. Studies that quantify the relative magnitude of the impact of different threats upon population trends have been published for only a limited number of populations (e.g. Gill et al. 2007, Schroeder et al. 2012, Douglas et al. 2014, Kentie et al. 2014, Duijns et al. 2015). Although individual populations of a number of species are the subject of detailed and long-term study (e.g. Gill et al. 2001b, Kleijn et al. 2010), and the deployment of tracking devices has revolutionised our understanding of the seasonal distribution and habitat requirements of a range of species (e.g. Ueta et al. 2002, Battley et al. 2012, Hooijmeijer et al. 2013, Senner et al. 2014), there is an urgent need for quantitative assessments of the relative importance of different drivers of population change for as many populations as possible.

\section{Disturbance}

Combined across all populations, human intrusion and disturbance was regarded as the most severe threat, particularly for non-breeding populations. Whilst there is evidence that disturbance can have localised impacts on the distribution of breeding birds (Pearce-Higgins et al. 2006, Holm and Laursen 2009), the scale of such disturbance in the breeding season currently appears unlikely to be extensive enough to have population-level impacts. Many Numeniini populations have large and remote breeding ranges that are likely to be subject to little or no disturbance. However, for species such as Eurasian Curlew and Black-tailed Godwit that extensively use farmed landscapes, or for populations that rely on a small number of key pre- or post-breeding sites, disturbance could potentially have a population-level impact.

Although it can be difficult to study, disturbance can affect the behaviour and distribution of individuals at staging and non-breeding sites, but there is so far little evidence it is having strong negative impacts on populations (e.g. Gill et al. 2001a, Finn et al. 2007, Peters and Otis 2007, Yasué et al. 2008). Despite having a high IMPACT score for non-breeding habitats, published evidence suggests that disturbance will affect wader populations only if it significantly reduces the utility of a high proportion of potential sites or affects a large number of individuals by preventing them from accessing undisturbed locations (Peters and Otis 2007), thereby reducing food intake (Gill et al. 2001a), increasing energetic costs (Rogers et al. 2006) or predation risk (Liley and Sutherland 2007). Whilst disturbance is widely regarded as a potential threat, the majority of published peer-reviewed studies do not appear to support this judgement. Either we have overestimated the importance of disturbance or an insufficient number of studies have been conducted in parts of the world where key sites are heavily disturbed. Reassuringly, our expert assessment did recognise the tension between our categorisation and the peer-reviewed literature, and acknowledged the evidence regarding the impact of disturbance is 'poor' in all cases (Appendix SI). Nonetheless, given the rapid and widespread increase in the level of disturbance, there is an urgent need to resolve this uncertainty.

\section{Development}

Residential and commercial development, drilling, mining and quarrying, and the construction of transportation and service corridors were regarded as having widespread and severe impacts on populations, especially in coastal non-breeding areas where they can result in significant changes in land use. In addition to the direct effects on habitat availability, roads can reduce the local density of breeding waders in surrounding fields (Reijnen and Foppen 1997, Melman et al. 2008, Fikenscher et al. 2015) leading to population level impacts when a high proportion of a population's breeding range is intersected by roads. Similarly, construction activity, whether associated with coastal development (Burton et al. 2002) or renewable energy (Pearce-Higgins et al. 2012), can have a localised impact on both breeding and non-breeding populations, with displaced birds 
likely to suffer increased mortality when they settle elsewhere (Burton et al. 2006). Furthermore, these studies suggest that where there is significant overlap between disturbance, habitat loss and habitat conversion, there is the potential for significant population-level impacts to occur.

The potential severity of these impacts is illustrated by recent trends in the Yellow Sea where $28 \%$ of intertidal habitats have been lost since the 1980s (Yang et al. 2011, Murray et al. 2014, Ma et al. 2014), likely leading to population declines in 22 of 25 migratory shorebird species using the EAAF (Hua et al. 2015). The remaining tidal flats are increasingly degraded (Melville et al. 2016), potentially preceding further loss and population decline (Conklin et al. 2016, Piersma et al. 2016). The high rate of change in the Yellow Sea, coupled with the fact that these threats were regarded as strongly increasing across the Pacific Americas, Central Americas and West Asian flyways, and during the non-breeding period in the Central Asian flyway (Szabo and Mundkur in press), means that residential and commercial development must be regarded as one of the strongest and most severe threats facing Numeniini, with negative impacts on adult survival having now been documented (Piersma et al. 2016, Conklin et al. 2016).

\section{Pollution}

Although there is little evidence (and few studies) of the direct effects of pollution on wader species (Currie and Valkama 1998), increasing levels of pollution is one of the threats contributing to the deterioration of the environment in the Yellow Sea (Barter 2002, Murray et al. 2015, Hua et al. 2015, Melville et al. 2016). Pollution has already resulted in algal blooms and the de-oxygenation of parts of the region, likely impacting the prey base for waders en route to their Arctic breeding grounds (Lopez et al. 2000). Increases in pollution frequently occur in conjunction with a number of land-use practices (e.g. land reclamation, development, transport, mining, agriculture and aquaculture) that contribute to a general deterioration of habitat availability and quality. Industrial activity along highly developed parts of the Yellow Sea coastline makes pollution a component of the suite of threats facing birds in the region (Barter 2002, Yang et al. 2011, Melville 2015). Elsewhere, where populations rely heavily on agricultural habitats, such as rice fields in Europe, Africa and the Americas, Numeniini may also be exposed to chemical contamination with uncertain impacts (Strum et al. 2010, Odino 2014, Dias et al. 2014).

\section{Terrestrial land-use change and predation}

The effects of agricultural and forestry intensification and expansion appeared to be less important than other development pressures, with some notable exceptions: across Europe, a large number of studies have identified negative impacts resulting from agricultural intensification on Black-tailed Godwit and Eurasian Curlew populations. For instance, the increased frequency of mowing and introduction of high stocking densities in agricultural grasslands increase both nest and chick mortality, whilst practices employed to enhance grass growth (drainage, reseeding, high levels of fertiliser inputs, rolling) reduce the quality of breeding habitats and diminish the growth rates of pre-fledging chicks. Combined, these effects have led to population declines (Berg 1992, 1994, Kruk et al. 1997, Schekkerman et al. 2008, 2009, Kentie et al. 2013, 2014). Similarly, the transition across much of Europe from hay meadows with a single cut, to silage with multiple cuts in a season, has turned many previously suitable grassland habitats into population sinks (Schekkerman et al. 2008, 2009). Large declines in breeding waders in Russia and northern Kazakhstan since the mid-20 $0^{\text {th }}$ century have also likely been driven by the conversion of virgin steppe into agriculture habitats (Morozov 2000, Soloviev 2005, 2012). Similar increases in the intensity of grazing and burning management in North America may also affect breeding populations there (Cochran and Anderson 1987, Sandercock et al. 2015). It is worth noting, however, that extensive grazing management can be an important tool to maintain appropriate condition for some Numeniini species by promoting heterogeneous semi-natural open habitats (e.g. PearceHiggins and Grant 2006, Sandercock et al. 2015). Determining the proper balance between the 
need to actively manage these habitats and the economic considerations of local landowners is a key conservation goal for the conservation of temperate breeding Numeniini.

Woodland or plantation forestry may have direct negative impacts through the loss and fragmentation of open breeding habitats (Ratcliffe 2007). It is also indirectly associated with population declines by driving increases in the abundance of avian and mammalian predators, which lead to a reduction in nesting success and local breeding population declines (Valkama et al. 1999, Pearce-Higgins et al. 2009a, Douglas et al. 2014). More broadly, there is strong evidence that high populations of generalist predators, in particular red foxes Vulpes vulpes (Berg 1992, Grant 1997, Valkama and Currie 1999, Grant et al. 1999) and Ravens Corvus corax (Ballantyne and Nol 2011) may limit populations, although in the UK, Raven population increases were not strongly associated with wader population declines (Amar et al. 2010). Although much of this evidence is from Europe, the loss of open habitats and agricultural intensification may also impact some North American breeding populations (Cochran and Anderson 1987). The deterioration of open breeding habitats thus appears to be the main threat facing temperate breeding populations across Europe and North America. These threats do not appear to be affecting other flyway populations to the same extent, potentially as the breeding populations of other species overlap less with areas of significant land-use change, or are more remote, and thus have a weaker evidence base (but see Senner et al. 2017).

\section{Climate change impacts and mitigation}

Climate change is regarded as being an increasing threat and having a significant impact across Central Americas, Atlantic Americas and East Atlantic flyways, and to be moderately increasing across the two Pacific flyways. For instance, Numeniini may be especially sensitive to alterations to the phenology and abundance of food resources during the breeding season (Pearce-Higgins 2010, Leito et al. 2014, Senner et al. 2017), although as yet, few breeding population changes having been quantitatively linked to climate change through these mechanisms (Senner 2012, Senner et al. 2017). Nevertheless, changes in woody plant distribution in the Arctic may already account for some localised population displacement of Arctic-nesting Whimbrel (Ballantyne and Nol 2015) and could potentially impact the southerly limit of populations more broadly in the future (Miller et al. 2014). An upwards shift in the altitudinal distribution of Eurasian Curlew breeding in the UK has also been documented (Massimino et al. 2015). There is evidence from the Netherlands that the impacts of climate change on breeding Black-tailed Godwits may be manifest through the combined impacts of temperature and agricultural management upon sward height and the timing of mowing (Kleijn et al. 2010).

Away from the breeding grounds, habitat loss due to sea-level rise may have a significant impact on the availability of suitable non-breeding stop-over locations, particularly for species dependent on intertidal mudflats or other low-lying areas (Mustin et al. 2007, Galbraith et al. 2014, Iwamura et al. 2014). The impact of rising sea-level is likely to be highly site-dependent, as a result of fine-scale variation in topography and the human approach to coastal defence (Galbraith et al. 2002), and may have varied and relatively subtle impacts on different Numeniini species depending upon the resulting changes in estuary sediment-type and productivity (Austin and Rehfisch 2003). For example, it is likely that the seawall constructed along much of the Chinese coast will reduce the resilience of coastal habitats in the Yellow Sea to sea-level rise (Ma et al. 2014).

During migration, changes in wind patterns and climatic conditions may also affect the phenology of individuals within populations. For example, individual baueri Bar-tailed Godwits are reliant on favourable wind conditions for successful migration. This population may therefore be highly vulnerable to changes in global weather patterns resulting from climate change (Gill et al. 2014). There is also evidence that recent climatic changes during migration may be constraining the ability of Hudsonian Godwits Limosa haemastica to return to their breeding grounds at Churchill, Manitoba (Senner 2012), causing them to mistime their breeding relative to local 
environmental phenology (Senner et al. 2017). Although this has not been demonstrated yet in other species, given the importance of breeding phenology as a mechanism for driving a cascade of population-level responses in some species (Gill et al. 2014), such impacts may affect many populations.

Increasing renewable energy development, such as wind farms, may also be a potential threat throughout the annual cycle, particularly for the East Atlantic and EAAF flyways. There is evidence for impacts of onshore wind farms on breeding Eurasian Curlew populations (PearceHiggins et al. 2009b, 2012), and potential for tidal barrages to affect passage or wintering wader populations (Clark 2006). However, as with other human developments, unless these overlap with a significant proportion of flyway populations, they are unlikely to have a significant, populationlevel impact (Pearce-Higgins and Green 2014). Given the importance of individual estuaries for particular populations (e.g. $42 \%$ of the baueri Bar-tailed Godwit and $20 \%$ of the Far Eastern Curlew population occurring at a single site in the Yellow Sea; Bai et al. 2015, Choi et al. 2015), the deployment of tidal barrages or large wind farms for renewable energy generation could have significant impacts upon particular populations. For example, the Dongsha Shoals off the Jiangsu coast, China, could support 40,000 turbines and pose a risk to these species through potential collisions and barrier effects (Melville et al. 2016).

\section{Hunting and harvesting}

As a group, Numeniini have long been affected by hunting (Gerasimov et al. 1997, Barbosa 2001, Graves 2010) and adult survival increases when hunting bans are implemented (Taylor and Dodd 2013, Watts et al. 2015). In the present study, hunting was regarded as a threat to some North American and Asian breeding populations, although there was considerable uncertainty about its severity and continued consequences (Page and Gill 1994). Hunting is still permitted in some European countries and can be significant; in France an estimated 10,000-15,000 Black-tailed Godwits were hunted per annum until a recent moratorium (Trolliet 2014). As hunting can still significantly impact wader populations (Zöckler et al. 2010), the need to quantify its potential impact for Numeniini, and to introduce and enforce control measures where evidence of sustainable take cannot be demonstrated, is likely to be urgent.

Along the Chinese coast, there is a significant amount of wader by-catch in fishing nets which may be killing tens of thousands of waders per year (Melville et al. 2016). In addition, unregulated harvesting of shellfish and expansion of the aquaculture industry is likely to further reduce non-breeding survival rates there. Certainly, excessive harvesting of shellfish in the UK and The Netherlands has been associated with reductions in Eurasian Curlew survival rates (Taylor and Dodd 2013), as well as impacts on other wader species (Atkinson et al. 2005, van Gils et al. 2006).

\section{Conclusions}

We have provided a summary of the best available knowledge of the threats to this group of declining migratory waders. By collating expert assessments from across the world, we have identified some important patterns and contrasts among flyways and life-stages to help shape future conservation action. We have also explicitly acknowledged key knowledge gaps to prioritise future research and monitoring needs. This approach could be usefully adopted for other groups of declining species, such as other shorebirds and long-distance migratory passerines, in order to gain further insights into the causes of their decline.

Globally, the greatest threats facing Numeniini populations appear to be large-scale development of key passage and non-breeding sites in coastal areas across East Asia, Europe and the Americas. Although there is some evidence that population trends of some species across these flyways have been in decline for many decades (Department of the Environment 2015), these threats have recently been identified as affecting a wide range of wader species, and require urgent action, particularly in the EAAF (Sutherland et al. 2012, Murray et al. 2014, Hua et al. 2015, 
Piersma et al. 2016). Similar rates of rapid development could occur at important stop-over and non-breeding sites outside of the EAAF and could be assessed using a combination of remote sensing techniques and field-surveillance (Murray et al. 2014). In the face of such rapid land-use change, the long-term persistence of threatened populations using these areas may critically depend upon the remaining key sites being identified, protected and managed. Additionally, in poorly surveyed or inaccessible regions, key sites could be identified through the large-scale deployment of new technologies, such as satellite tracking (e.g. Battley et al. 2012). Identifying and protecting key non-breeding sites from unsustainable development around the world is the highest priority action identified by this assessment.

Significant land-use change on the breeding grounds, particularly through agricultural intensification, which is being exacerbated by increasing populations of generalist predators, appears to be the main threat identified in Europe, and may also affect some North American species. These impacts are probably not so widespread as on the non-breeding grounds, because many Numeniini breed across less-intensively managed wetland, upland or tundra habitats. However, there is the potential for significant impacts to increase across these breeding habitats if they are drained or developed further, or if human expansion into these areas results in significant increases in generalist predator populations. Given the relatively restricted range of some subarctic breeding Numeniini to areas close to the treeline, shrub and tree encroachment and subsequent increases in predator populations could also be a major threat, even in more remote regions. Population monitoring should be prioritised if these threats are to be identified in a timely manner. This will be challenging for species that occupy extensive or remote regions at low densities, and may be best achieved where individuals are concentrated at key non-breeding locations (e.g. Clark et al. 2004, Beale et al. 2006, Senner and Angulo-Pratalongo 2013). In many such instances, in order to effectively link winter and breeding areas, remote tracking of individuals will be required (e.g. Johnson et al. 2016). This could be particularly useful for the West Asian flyway, where there is a high degree of uncertainty in our assessment of threats to the region's breeding populations, and other particularly poorly known populations, such as alboaxillaris Whimbrel and Asian populations of limosa Black-tailed Godwit.

The open availability of satellite imagery provides valuable opportunities to identify environmental change across extensive breeding areas (Turner et al. 2015). For many Numeniini, it will probably be necessary to combine multiple monitoring efforts including censuses at non-breeding sites, satellite tracking to establish migratory connectivity, and remote sensing of habitat change, to generate a complete picture of their conservation status. Where possible, more detailed demographic monitoring of sample populations could complement such surveillance, enabling population vital rates to be identified, and highlighting where and when in the annual cycle bottlenecks occur (e.g. Robinson et al. 2014, Rakhimberdiev et al. 2015, Piersma et al. 2016).

In addition to site-protection and monitoring needs, this study has also emphasised that where species still occur in heavily modified landscapes, such as across much of Europe, many wader populations are declining (BirdLife International 2015a), and may require significant conservation management to persist. This could include the control of predators or non-lethal management of predation risk (Fletcher et al. 2010) and the adoption of relevant agri-environment scheme measures (Smart et al. 2014). While the evidence for agri-environment schemes benefiting waders is mixed ( $\mathrm{O}^{\prime}$ Brien and Wilson 2011, Kentie et al. 2015), there is an urgent need to identify and implement the most effective actions more widely. Achieving tangible conservation success at the national or international scale will likely require dedicated programmes targeting species at risk. For example, the Eurasian Curlew is now considered the UK's highest conservation priority bird species by some, and the subject of a major recovery programme bringing together research, advocacy and conservation delivery (Brown et al. 2015). Robust monitoring of populations would help to measure the success of any conservation interventions.

A combination of site protection, active management, population monitoring and individual tracking, which could be facilitated through specific recovery programmes, should reduce the likelihood of extinction of the remaining Numeniini populations and species. Given the multitude 
of threats most populations face across large geographic regions, this will probably best be achieved by coordination through intergovernmental treaties such as the Convention on Migratory Species (CMS) and Ramsar, or flyway-specific treaties such as the Agreement on the Conservation of African-Eurasian Migratory Waterbirds (AEWA), Western Hemisphere Shorebird Reserve Network (WSHRN) and the East Asian-Australasian Flyway Partnership (EAAFP) to generate the political will, international collaboration and conservation resourcing required to be effective. The long-term future of these populations may ultimately depend upon whether sufficient international efforts can be focussed to enable the necessary monitoring, research and conservation actions to be implemented rapidly across each species' and population's annual cycle.

\section{Supplementary Material}

To view supplementary material for this article, please visit https://oi.org/10.1017/ So959270916000678

\section{Acknowledgements}

We are grateful to all those experts who in addition to the authors, submitted questionnaire responses, and which provided the foundation of the subsequent scoring and assessment: Brad Andres, Aleksey I. Antonov, Antonio Araújo, Yves Aubry, Jon Bart, Phil Battley, Heinrich Belting, Natalie Busch, Emmanuel Caillot, Simba Chan, Nigel Clark, Rob Clemens, Olivia Crowe, Ian Davidson, Victor Degtyaryev, Simon Delany, Sergey Dereliev, Anita Donaghy, Dmitry Dorofeev, Guillermo J. Fernández Aceves, Ysbrand Galama, Gerrit Gerritsen, Robert Gill Jr, Sundev Gombobaatar, Patricia M. González, Cheri Gratto-Trevor, Tómas Grétar Gunnarsson, Jorge Sanchez Gutierrez, Meredith Gutowski, Jannik Hansen, Hermann Hötker, Eve Iversen, Sharif Jbour, Angharad Jones, Lilja Jóhannesdóttir, Stephanie Jones, Ian Karika, Peter Köhler, Borgný Katríndóttir, Fedor Kazansky, David Kleijn, Jan Kube, Arne Lesterhuis, Jutta Leyrer, Golo Maurer, Pat Minton, Vladimir Morozov, Szabolcs Nagy, Mark O’Brien, Gerenda Olsthoorn, Cynthia Pekarik, Allan Perkins, Alfonso Duarte los Res Roda, Philippe Raust, Marc van Roomen, Phillip Round, Thijs Sanderink, Brett Sandercock, Gregor Scheiffarth, Stan Senner, Paul Allan Smith, Julie Paquet, Fletcher Smith, Kristine Sowl, Fernando Spina, Colin Studds, David Stroud, David Tate, Lee Tibbitts, Ivo Walsmit, Nils Warnock, Jim Wilson, Eddy Wymenga, Alexander Yurlov, Yuri Zharikov, and Leo Zwarts. We also thank the International Wader Study Group for assisting us with the hosting of the one-day workshop in Wilhelmshaven, Germany, on 3oth September 2013. Any use of trade names is for descriptive purposes only and does not imply endorsement by the U.S. Government. This research received no specific grant from any funding agency, commercial or not-for-profit sectors.

\section{References}

Alves, J. A., Gunnarsson, T. G., Hayhow, D. B., Appleton, G. F., Potts, P. M., Sutherland, W. J. and Gill, J. A. (2013) Costs, benefits and fitness consequences of different migratory strategies. Ecology 94: 11-17.

Amar, A., Redpath, S., Sim, I. and Buchanan, G. (2010) Spatial and temporal associations between recovering populations of common raven Corvus corax and British upland wader populations. J. Appl. Ecol. 47: 253-262.

Atkinson, P. W., Clark, N. A., Dodd, S. G. and Moss, D. (2005) Changes in fisheries practices and oystercatcher survival, recruitment and body mass in a marginal cockle fishery. Ardea 93: 199-212.

Austin, G. E. and Rehfisch, M. M. (2003) The likely impact of sea level rise on waders (Charadrii) wintering on estuaries. J. Nat. Cons. 11: 43-58.

Bai, Q., Chen, J., Chen, Z., Dong, G., Dong, J., Dong, W., Fu, V. W. K., Han, Y., Lu, G., Li, Y., Liu, Y., Lin, Z., Meng, D., Martinez, J., Ni, G., Shan, K., Sun, R., Tian, S., Wang, F., $\mathrm{Xu}$, Z., Yu, Y.-T., Ying, J., Yang, Z., Zhang, L., 
Zhang, M., Zeng, X. and China Coastal Waterbirds Census Group (2015) Identification of coastal wetlands of international importance for waterbirds: a review of China Coastal Waterbird Surveys 2005-2013. Avian Res. 6: 12.

Balachandran, S. (2006) The decline in wader populations along the east coast of India with special reference to Point Calimere, south-east India. Pp. 296-301 in C. Boere, C. A. Galbraith and D. A. Stroud., eds. Waterbirds around the world. Edinburgh, UK: The Stationery Office.

Ballantyne, K. and Nol, E. (2011) Nesting habitat selection and hatching success of Whimbrels near Churchill, Manitoba, Canada. Waterbirds 34: 151-159.

Ballantyne, K. and Nol, E. (2015) Localized habitat change near Churchill, Manitoba and the decline of nesting Whimbrels (Numenius phaeopus). Polar Biol. 38: 529-537.

Barbosa, A. (2001) Hunting impacts on waders in Spain: effects of species protection measures. Biodivers. Conserv. 10: 1703-1709.

Barter, M. A. (2002) Shorebirds of the Yellow Sea: Importance, threats and conservation status. Canberra, Australia: Wetlands International. (Global Series 9, International Wader Studies 12).

Battley, P. F., Warnock, N., Tibbitts, T. L., Gill, R. E. Jr, Piersma, T., Hassell, C. J., Douglas, D. C., Mulcahy, D. M., Gartrell, B. D., Schuckard, R., Melville, D. S. and Riegen, A. C. (2012) Contrasting extreme longdistance migration patterns in bar-tailed godwits Limosa lapponica. J. Avian Biol. 43: 21-32.

Beale, C. M., Dodd, S. and Pearce-Higgins, J. W. (2006) Wader recruitment indices suggest nesting success is temperature-dependent in Dunlin Calidris alpina. Ibis 148: 405-410.

Berg, A. (1992) Factors affecting nest-site choice and reproductive success of Curlews Numenius arquata on farmland. Ibis 132: 44-51.

Berg, A. (1994) Maintenance of populations and causes of population changes of curlews Numenius arquata breeding on farmland. Biol. Conserv. 67: 233-238.

BirdLife International (2010) The BirdLife checklist of the birds of the world, with conservation status and taxonomic sources.
Version 3. Downloaded from http://www. birdlife.info/docs/SpcChecklist/Checklist_ v3_Juneı.zip.

BirdLife International (2015a) European Red List of Birds. Luxembourg: Office for Official Publications of the European Commission.

BirdLife International (2015b) IUCN Red List for birds. Downloaded from http://www. birdlife.org on 12/11/2015.

Boere, G. C., Galbraith, C. A. and Stroud, D. A. (2006) Waterbirds around the world. Edinburgh, UK: The Stationery Office.

Brown, D., Crockford, N. and Sheldon, R. (2014) Drivers of population change and conservation priorities for the Numeniini populations of the world. Conservation statements for the 13 species and 38 biogeographic populations of curlew, godwits and the upland sandpiper. UNEP/CMS/ COPıI/Inf.33. Available at www.cms.int/ en/document/conservation-statementsnumeniini-species.

Brown, D., Wilson, J., Douglas, D., Thompson, P., Foster, S., McCulloch, N., Phillips, J., Stroud, D. and Whitehead, S. (2015) The Eurasian Curlew - the most pressing bird conservation priority in the UK? Brit. Birds 108: 660-668.

Burton, N. H. K., Rehfisch, M. M. and Clark, N. A. (2002) Impacts of disturbance from construction work on the densities and feeding behaviour of waterbirds using the intertidal mudflats of Cardiff Bay, UK. Environ. Manage. 30: 865-871.

Burton, N. K., Rehfisch, M. M., Clark, N. A. and Dodd, S. G. (2006) Impacts of sudden winter habitat loss on the body condition and survival of redshank Tringa totanus. J. Appl. Ecol. 43: 464-473.

Butchart, S. H. M., Walpole, M., Collen, B., van Strien, A., Scharlemann, J. P. W., Almond, R. E. A., Baillie, J. E. M., Bomhard, B., Brown, C., Bruno, J., Carpenter, K. E., Carr, G. M., Chanson, J., Chenery, A. M., Csirke, J., Davidson, N. C., Dentener, F., Foster, M., Galli, A., Gallloway, J. N., Genovesi, P., Gregory, R. D., Hockings, M., Kapos, V., Lamarque, J.-F., Leverington, F., Loh, J., McGeoch, M. A., McRae, L., Minasyan, A., Hernández Morcillo, M., Oldfield, T. E. E., Pauly, D., Quader, S., Revenga, C., Sauer, J. R., Skolnik, B., Spear, D., Stanwell-Smith, D., 
Stuart, S. N., Symes, A., Tierney, M., Tyrrell, T. D., Vié, J.-C. and Watson, R. (2010) Global biodiversity: indicators of recent declines. Science 328: 1164-1168.

Choi, C.-Y., Battley, P. F., Potter, M. A., Rogers, K. G. and Ma, Z. J. (2015) The importance of Yalu Jiang coastal wetland in the north Yellow Sea to Bar-tailed Godwits Limosa lapponica and Great Knots Calidris tenuirostris during northward migration. Bird Conserv. Internatn. 25: 53-70.

Clark, J. A., Robinson, R. A., Clark, N. A. and Atkinson, P. W. (2004) Using the proportion of juvenile waders in catches to measure recruitment. Wader Study Group Bull. 104: 51-55.

Clark, N. A. (2006) Tidal barrages and birds. Ibis 148: 152-157.

Cochran, J. F. and Anderson, S. H. (1987) Comparison of habitat attributes at sites of stable and declining long-billed curlew populations. The Great Basin Naturalist 47: 459-466.

Colwell, M. A. (2010) Shorebird ecology, conservation and management. Berkley and Los Angeles, California: University of California Press.

Conklin, J. R., Verkuil, Y. I. and Smith, B. R. (2014) Prioritizing migratory shorebirds for conservation action on the East AsianAustralasian Flyway. Hong Kong: WWFHong Kong.

Conklin, J. R., Lok, T., Melville, D. S., Riegen, A. C., Schuckard, R., Piersma, T. and Battley, P. F. (2016) Declining adult survival of New Zealand Bar-tailed Godwits during 20052012 despite apparent population stability. Ети 116: 147-157.

Currie, D. and Valkama, J. (1998) Limited effects of heavy metal pollution on foraging and breeding success in the curlew (Numenius arquata). Environ. Pollut. 101: 253-261.

Department of the Environment (2015) Numenius madagascariensis in Species Profile and Threats Database. Canberra, Australia: Department of the Environment. Downloaded from http://www.environment. gov.au/sprat on $13 / 11 / 15$.

Dias, R. A., Blanco, D. E., Goijman, A. P. and Zaccagnini, M. E. (2014) Density, habitat use, and opportunities for conservation of shorebirds in rice fields in southeastern South America. Condor 116: 384-393.

Douglas, D. J. T., Bellamy, P. E., Stephen, L. S., Pearce-Higgins, J. W., Wilson, J. D. and Grant, M. C. (2014) Upland land use predicts population decline in a globally nearthreatened wader. J. Appl. Ecol. 51: 194-203.

Duijns, S., van Gils, J. A., Smart, J. and Piersma, T. (2015) Phenotype-limited distributions: short-billed birds move away during times that prey bury deeper. R. Soc. Open Sci. 2: 150073 .

Faaborg, J., Holmes, R. T., Anders, A. D., Bildstein, K. L., Dugger, K. M., Gauthreaux, S. A., Heglund, P., Hobson, K. A., Jahn, A. E., Johnson, D. H., Latta, S. C., Levey, D. J., Marra, P., Merkord, C. L., Nol, E., Rothstein, S. I., Sherry, T. W., Sillett, T. S., Thompson, F. R. and Warnock, N. (2010a) Conserving migratory land birds in the New World: Do we know enough? Ecol. Appl. 20: $398-418$.

Faaborg, J., Holmes, R. T., Anders, A. D., Bildstein, K. L., Dugger, K. M., Gauthreaux, S. A., Heglund, P., Hobson, K. A., Jahn, A. E., Johnson, D. H., Latta, S. C., Levey, D. J., Marra, P. P., Merkord, C. L., Nol, E., Rothstein, S. I., Sherry, T. W., Sillett, T. S., Thompson, F. R. and Warnock, N. (2010b) Recent advances in understanding migration systems of New World land birds. Ecol. Monogr. 80: 3-48.

Fikenscher, A., Hooijmeijer, J., Kentie, R. and Piersma, T. (2015) Black-tailed Godwits avoid traffic-intense roads less in high quality breeding habitat. De Levende Natuur 116: 51-56.

Finn, G., Catterall, C. P. and Driscoll, P. V. (2007) Determinants of preferred intertidal feeding habitat for Eastern Curlew: A study at two spatial scales. Austral Ecol. 32: 131-144.

Fletcher, K., Aebischer, N. J., Baines, D., Foster, R. and Hoodless, A. N. (2010) Changes in breeding success and abundance of groundnesting moorland birds in relation to the experimental deployment of legal predator control. J. Appl. Ecol. 47: 263-272.

Gailbraith, H., Jones, R., Park, R., Clough, J., Herrod-Julius, S., Harrington, B. and Page, G. (2002) Global climate change and sea level rise: potential losses of intertidal habitat for shorebirds. Waterbirds 25: 173-183. 
Galbraith, H., DesRochers, D. W., Brown, S. and Reed, J. M. (2014) Predicting vulnerabilities of North American shorebirds to climate change. PLOS ONE 9: e108899.

Gaston, K. J. and Blackburn, T. M. (1995) Birds, body size and the threat of extinction. Phil. Trans. R. Soc. Lond. B 347: 205-212.

Gerasimov, Y. N., Artukhin, Y. B. and Gerasimov, N. N. (1997) The eastern curlew Numenius madagascariensis in Kamchatka, Russia. Stilt 30: 14-15.

Gibbons, D. W., Wilson, J. D. and Green, R. E. (2011) Using conservation science to solve conservation problems. J. Appl. Ecol. 48: 505-508.

Gibson, R. and Baker, A. J. (2012) Multiple gene sequences resolve phylogenetic relationships in the shorebird suborder Scolopaci (Aves: Charadriiformes). Mol. Phylogenet. Evol. 64: 66-72.

Gill, J. A., Norris, K. and Sutherland, W. J. (2001a) The effects of disturbance on habitat use by black-tailed godwits Limosa limosa. J. Appl. Ecol. 38: 848-856.

Gill, J. A., Norris, K., Potts, P. M., Gunnarsson, T. G., Atkinson, P. W. and Sutherland, W. J. (2001b) The buffer effect and large-scale population regulation in migratory birds. Nature 412: 436-438.

Gill, J. A., Langston, R. H. W., Alves, J. A., Atkinson, P. W., Bocher, P., Cidraes Vieira, N., Crockford, N. J., Gélinaud, G., Groen, N., Gunnarsson, T. G., Hayhow, B., Hooijmeijer, J., Kentie, R., Kleijn, D., Lourenço, P. M., Masero, J. A., Meunier, F., Potts, P. M., Roodbergen, M., Schekkerman, H., Schröder, J., Wymenga, E. and Piersma, T. (2007) Contrasting trends in two Black-tailed Godwit populations: a review of causes and recommendations. Wader Study Group Bull. 114: 43-50.

Gill, J. A., Alves, J. A., Sutherland, W. J., Appleton, G. F., Potts, P. M. and Gunnarsson, T. G. (2014) Why is the timing of bird migration advancing when individuals are not? Proc. R. Soc. B 281: 20132161.

Gill, R. E. Jr, Tibbitts, T. L., Douglas, D. C., Handel, C. M., Mulcahy, D. M., Gottschalck, J. C., Warnock, N., McCaffery, B. J., Battley, P. F. and Piersma, T. (2009) Extreme endurance flights by landbirds crossing the Pacific Ocean: ecological corridor rather than barrier? Proc. R. Soc. B 276: 447-457.
Gill, R. E. Jr, Douglas, D. C., Handel, C. M., Tibbitts, T. L., Hufford, G. and Piersma, T. (2014) Hemispheric-scale wind selection facilitates bar-tailed godwit circum-migration of the Pacific. Anim. Behav. 90: 117-130.

Gunnarsson, T. G., Gill, J. A., Newton, J., Potts, P. M. and Sutherland, W. J. (2005) Seasonal matching of habitat quality and fitness in a migratory bird. Proc. R. Soc. $B$ 272: 2319-2323.

Grant, M. C. (1997) Breeding curlew in the UK: RSPB research and implications for conservation. RSPB Conserv. Rev. 11: 67-73.

Grant, M. C., Orsman, C., Easton, J., Lodge, C., Smith, M., Thompson, G., Rodwell, S. and Moore, N. (1999) Breeding success and causes of breeding failure of curlew Numenius arquata in Northern Ireland. J. Appl. Ecol. 36 : 59-74.

Graves, G. R. (2010) Late $19^{\text {th }}$ Century abundance trends of the Eskimo curlew on Nantucket Island, Massachusetts. Waterbirds 33: 236-241.

Harris, S. J., Massimino, D., Newson, S. E., Eaton, M. A., Balmer, D. E., Noble, D. G., Musgrove, A. J., Gillings, S., Procter, D. and Pearce-Higgins, J. W. (2015) The Breeding bird survey 2014. Thetford, UK: British Trust for Ornithology. (BTO Research Report 673).

Holm, T. E. and Laursen, K. (2009) Experimental disturbance by walkers affects behaviour and territory density of nesting Black-tailed Godwit Limosa limosa. Ibis 151: 77-87.

Hooijmeijer, J. C. E. W., Senner, N. R., Tibbitts, T. L., Gill, R. E., Jr, Douglas, D. C., Bruinzeel, L. W., Wymenga, E. and Piersma, T. (2013) Post-breeding migration of Dutch-breeding black-tailed godwits: timing, routes, use of stopovers, and nonbreeding distributions. Ardea 101: 141-152.

Hua, N., Tan, K., Chen, Y. and Ma, Z. (2015) Key research issues concerning the conservation of migratory shorebirds in the Yellow Sea region. Bird Conserv. Internatn. 25:38-52.

Iwamura, T., Fuller, R. A. and Possingham, H. P. (2014) Optimal management of a multispecies shorebird flyway under sea-level rise. Conserv. Biol. 28: 1710-1720.

Johnson, A., Perz, J., Nol, E. and Senner, N. (2016) Dichotomous strategies: The migration of Whimbrel (Numenius phaeopus) 
breeding in the Eastern Canadian SubArctic. J. Field Ornithol. 87: 371-383.

Julliard, R., Jiguet, F. and Couvet, D. (2003) Common birds facing global changes: what makes a species at risk? Glob. Change Biol. 10: 148-154.

Kentie, R., Hooijmeijer, J. C. E. W., Trimbos, K. B., Groen, N. M. and Piersma, T. (2013) Intensified agricultural use of grasslands reduces growth and survival of precocial shorebird chicks. J. Appl. Ecol. 50: 243-251.

Kentie, R., Both, C., Hooijmeijer, J. C. E. W. and Piersma, T. (2014) Age-dependent dispersal and habitat choice in black-tailed godwits Limosa limosa limosa across a mosaic of traditional and modern grassland habitats. J. Avian Biol. 45: 396-405.

Kentie, R., Both, C., Hooijmeijer, J. C. E. W. and Piersma, T. (2015) Management of modern agricultural landscapes increases nest predation rates in Black-tailed Godwits Limosa limosa. Ibis 157: 614-625.

Kleijn, D., Schekkerman, H., Dimmers, W. J., Van Kats, R. J. M., Melman, D. and Teunissen, W. A. (2010) Adverse effects of agricultural intensification and climate change on breeding habitat quality of Black-tailed Godwits Limosa l. limosa in the Netherlands. Ibis 152: 475-486.

Kruk, M., Noordervllet, M. A. W and ter Keurs, W. J. (1997) Survival of black-tailed godwit chicks Limosa limosa in intensively exploited grassland areas in The Netherlands. Biol. Conserv. 80: 127-133.

Kuhnert, P. M., Martin, T. G. and Griffiths, S. P. (2010) A guide to eliciting and using expert knowledge in Bayesian ecological models. Ecol. Lett. 13: 900-914.

Leito, A., Elts, J., Mägi, E., Truu, J., Ivask, M., Kuu, A., Ööpik, M., Meriste, M., Ward, R., Kuresoo, A., Pehlak, H., Sepp, H., Sepp, K. and Luigejõe, L. (2014) Coastal grassland wader abundance in relation to breeding habitat characteristics in Matsula Bay, Estonia. Ornis Fennica 91: 149-165.

Liley, D. and Sutherland, W. J. (2007) Predicting the population consequences of human disturbance for Ringed Plovers Charadrius hiaticula: a game theory approach. Ibis 149 S1: 82-94.

Lopez, R. J., Pardal, M. A. and Marques, J. C. (2000) Impact of macroalgal blooms and wader predation on intertidal macroinvertebrates: experimental evidence from the Mondego estuary (Portugal). J. Exp. Mar. Biol. Ecol. 249: 165-179.

Ma, Z., Melville, D. S., Liu, J., Chen, Y., Yang, H., Ren, W., Zhang, Z., Piersma, T. and Li, B. (2014) Rethinking China's new great wall. Massive seawall construction in coastal wetlands threatens biodiversity. Science 346: 912-914.

Massimino, D., Johnston, A. and PearceHiggins, J. W. (2015) The geographical range of British birds expands during 15 years of warming. Bird Study 62: 523-534.

Melman, T. C. P., Schotman, A. G. M., Hunink, S. and de Snoo, G. R. (2008) Evaluation of meadow bird management, especially blacktailed godwit (Limosa limosa limosa) in the Netherlands. J. Nat. Conserv. 16: 88-95.

Melville, D. S. (2015) Tianjin's tragic explosions highlight risks to the coastal environment from China's expanding chemical industries. Wader Study 122: 85-86.

Melville, D. S., Chen, Y. and Ma, Z. J. (2016) Shorebirds along China's Yellow Sea coast face an uncertain future - a review of threats. Ети 116: 100-110.

Miller, E. V., Nol, E., Nguyen, L. and Turner, D. (2014) Habitat selection and nest success of the Upland Sandpiper (Bartramia longicauda) in Ivvavik National Park, Yukon, Canada. Can. Field. Nat. 128: 341-349.

Morozov, V. V. (2000) Current status of the southern subspecies of the Whimbrel Numenius phaeopus alboaxillaris Lowe 1921 in Russia and Kazakhstan. Wader Study Group Bull. 92: 30-37.

Murray, N. J., Clements, R. S., Phinn, S. R., Possingham, H. P. and Fuller, R. A. (2014) Tracking the rapid loss of tidal wetlands in the Yellow Sea. Front. Ecol. Environ. 12: $267-272$.

Murray, N. J., Ma, Z. and Fuller, R. A. (2015) Tidal flats of the Yellow Sea: A review of ecosystem status and anthropogenic threats. Austral Ecol. 40: 472-481.

Mustin, K., Sutherland, W. J. and Gill, J. A. (2007) The complexity of predicting climateinduced ecological impacts. Climate Res. 35: 165-175.

O'Brien, M. and Wilson, J. D. (2011) Population changes of breeding waders on farmland in 
relation to agri-environment management. Bird Study 58: 399-408.

Odino, M. (2014) The power of poison: pesticide poisoning of Africa's wildlife. Ann. NY. Acad. Sci. 1332: 1-20.

O'Neill, S., Osborn, T., Hulme, M., Lorenzoni, I. and Watkinson, A. (2008) Using expert knowledge to assess uncertainties in future polar bear populations under climate change. J. Appl. Ecol. 45: 1649-1659.

Owens, I. P. F. and Bennett, P. M. (200o) Ecological basis of extinction risk in birds: habitat loss versus human persecution and introduced predators. P. Natl. Acad. Sci. USA 97: 12144-12148.

Page, G. W. and Gill, R. E. Jr (1994) Shorebirds in western North America: late 1800 s to late 1900. Stud. Avian Biol. 15: 147-160.

Pearce-Higgins, J. W. (2010) Using diet to assess the sensitivity of northern and upland birds to climate change. Climate Res. 45: 119-130.

Pearce-Higgins, J. W., Beale, C. M., Wilson, J. and Bonn, A. (2006) Analysis of moorland breeding bird distribution and change in the Peak District. Edale, UK: Moors for the Future Partnership. (Moors for the Future Report 1I).

Pearce-Higgins, J. W. and Grant, M. C. (2006) Relationships between bird abundance and the composition and structure of moorland vegetation. Bird Study 53:112-125.

Pearce-Higgins, J. W., Grant, M. C., Beale, C. M., Buchanan, G. M. and Sim, I. M. W. (2009a) International importance and drivers of change of upland bird populations. Pp. 209-227 in A. Bonn, T. Allot, K. Hubacek and J. Stewart, eds. Drivers of environmental change in uplands. London and New York: Routledge.

Pearce-Higgins, J. W. and Green, R. E. (2014) Birds and climate change: Impacts and conservation responses. Cambridge, UK: Cambridge University Press.

Pearce-Higgins, J. W., Stephen, L., Douse, A. and Langston, R. H. W. (2012) Greater impacts of wind farms on bird populations during construction than subsequent operation: results of a multi-site and multi-species analysis. J. Appl. Ecol. 49: 386-394.

Pearce-Higgins, J. W., Stephen, L., Langston, R. H. W., Bainbridge, I. P. and Bullman, R. (2009b) The distribution of breeding birds around upland wind farms. J. Appl. Ecol. 46: 1323-1331.

Peters, K. A. and Otis, D. L. (2007) Shorebird roost-site selection at two temporal scales: is human disturbance a factor? J. Appl. Ecol. 44: 196-209.

Piersma, T., van Gils, J., and Wiersma, P. (1996) Family Scolopacidae (sandpipers, snipes and phalaropes). Pp. 444-533 in J. del Hoyo, A. Elliott, and J. Sargatal, eds. Handbook of the birds of the world. Vol. 3. Hoatzin to auks. Barcelona: Lynx Edicions.

Piersma, T. and Baker, A. J. (2000) Life history characteristics and the conservation of migratory shorebirds. Pp. 105-124 in L. M. Gosling and W. J. Sutherland, eds. Behaviour and conservation. Cambridge: Cambridge University Press.

Piersma, T., Lok, T., Chen, Y., Hassell, C. J., Yang, H.-Y., Boyle, A., Slaymaker, M., Chan, Y.-C., Melville, D. S., Zhang, Z.-W. and Ma, Z. (2016) Simultaneous declines in summer survival of three shorebird species signals a flyway at risk. J. Appl. Ecol. 53: 479-490.

Rakhimberdiev, E., van den Hout, P. J., Brugge, M., Spaans, B. and Piersma, T. (2015) Seasonal mortality and sequential density dependence in a migratory bird. J. Avian Biol. 46: 332-341.

Ratcliffe, D. (2007) Galloway and the borders. London, UK: Collins.

Reijnen, R. and Foppen, R. (1997) Disturbance by traffic of breeding birds: evaluation of the effect and considerations in planning and managing road corridors. Biodivers. Conserv. 6: $567-581$.

Robbins, C. S., Sauer, J. R., Greenberg, R. S. and Droege, S. (1989) Population declines in North American birds that migrate to the neotropics. P. Natl. Acad. Sci. USA 86: $7658-7662$.

Roberts, D. L. and Jarić, I. (2016) Inferring extinction in North American and Hawaiian birds in the presence of sighting uncertainty. PeerJ 4: e2426

Robinson, R. A., Morrison, C. A. and Baillie, S. R. (2014) Integrating demographic data: towards a framework for monitoring wildlife populations at large spatial scales. Method. Ecol. Evol. 5: 1361-1372. 
Rogers, D. I., Piersma, T. and Hassell, C. J. (2006) Roost availability may constrain shorebird distribution: Exploring the energetic costs of roosting and disturbance around a tropical bay. Biol. Conserv. 133: 225-235.

Runge, C. A., Watson, J. E. M., Butchart, S. H. M., Hanson, J. O., Possingham, H. P. and Fuller, R. A. (2015) Protected areas and global conservation of migratory birds. Science 350 : 1255-1258.

Sæther, B.-E. and Bakke, Ø. (200o) Avian life history variation and contribution of demographic rates to the population growth rate. Ecology 81: 642-653.

Salafsky, N., Salzer, D., Stattersfield, A. J., Hilton-Taylor, C., Neugarten, R., Butchart, S. H. M., Collen, B., Cox, N., Master, L. L., O'Connor, S. O. and Wilkie, D. (2008) A standard lexicon for biodiversity conservation: unified classifications of threats and actions. Conserv. Biol. 22: 897-911.

Sandercock, B. K., Alfaro-Barrios, M. Casey, A. E., Johnson, T. N., Mong, T. W., Odom, K. J., Strum, K. M., and Winder, V. L. (2015) Effects of grazing and prescribed fire on resource selection and nest survival of Upland Sandpipers in an experimental landscape. Landscape Ecol. 30: 325-337.

Sanderson, F. J., Donald, P. F., Pain, D. J., Burfield, I. J. and van Bommel, F. P. J. (2006) Long-term population declines in AfroPalearctic migrant birds. Biol. Conserv. 131: 93-105.

Schekkerman, H., Teunissen, W. and Oosterveld, E. (2008) The effect of 'mosaic management' on the demography of blacktailed godwit Limosa limosa on farmland. J. Appl. Ecol. 45: 1067-1075.

Schekkerman, H., Teunissen, W. and Oosterveld, E. (2009) Mortality of Blacktailed Godwit Limosa limosa and Northern Lapwing Vanellus vanellus chicks in wet grasslands: influence of predation and agriculture. J. Ornithol. 150: 133-145.

Schroeder, J., Piersma, T., Groen, N. M., Hooijmeijer, J. C. E. W., Kentie, R., Lourenço, P. M., Schekkerman, H. and Both, C. (2012) Reproductive timing and investment in relation to spring warming and advancing agricultural schedules. J. Ornithol. 153:327-336.

Senner, N. R. (2012) One species but two patterns: Populations of the Hudsonian Godwit
(Limosa haemastica) differ in spring migration timing. Auk 129: 670-682.

Senner, N. R. and Angulo-Pratalongo, F. (2013) Atlas de las aves playeras del Perú: Sitios importantes para su conservación. Lima, Peru: Ministerio del Medio Ambiente and U.S. Fish and Wildlife Service.

Senner, N. R., Hochachka, W. M., Fox, J., and Afanasyev, V. (2014) An exception to the rule: Carry-over effects do not accumulate in a migratory bird. PLOS ONE 9: e86588.

Senner, N. R., Conklin, J. R. and Piersma, T. (2015) An ontogenetic perspective on individual differences. Proc. R. Soc. B 282 : 20151050.

Senner, N. R., Stager, M. and Sandercock, B. (2017) Ecological mismatches are moderated by local conditions for two populations of a long-distance migratory bird. Oikos 126: 61-72.

Smart, J., Wotton, S. R., Dillon, I. A., Cooke, A. I., Diack, I., Drewitt, A. L., Grice, P. V. and Gregory, R. D. (2014) Synergies between site protection and agri-environment schemes for the conservation of waders on lowland wet grasslands. Ibis 156: 576-590.

Soloviev, S. A. (2005) Birds of Omsk and its suburb. Novosibirsk, Russian Federation: Nauka. (In Russian).

Soloviev, S. A. (2012) Birds of Tobolo-Irtish forest-steppe and steppe: Western Siberia and Northern Kazakhstan. Pp. 212-294 in L. G. Vartapetov, ed. Spatial structure and organization of ornithocomplexes. Vol. 1 . Novosibirsk, Russian Federation: Publishing House SO RAN. (In Russian).

Strum, K. M., Hooper, M. J., Johnson, K. A., Lanctot, R. B., Zaccagnini, M. E. and Sandercock, B. K. (2010) Exposure of nonbreeding migratory shorebirds to cholinesterase inhibiting contaminants in the Western Hemisphere. Condor 112: 15-28.

Sullivan, M. J. P., Newson, S. E. and PearceHiggins, J. W. (2015) Using habitat-specific population trends to evaluate consistency of the effects of species traits on bird population change. Biol. Conserv. 192: 343-352.

Sutherland, W. J., Alves, J. A., Amano, T., Chang, C. H., Davidson, N. C., Max Finlayson, C., Gill, J. A., Gill, R. E., González, P. M., Gunnarsson, T. G., Kleijn, D., Spray, C. J., Székely, T. and Thompson, D. B. A. (2012) 
A horizon scanning assessment of current and potential future threats to migratory shorebirds. Ibis 154: 663-679.

Szabo, J. and Mundkur, T. (In Press) Conserving wetlands for migratory waterbirds in South Asia. In Prusty, B. A. K., Chandra, R. and Azeez, P.A., eds. Wetland science:Perspectives from South Asia. Berlin, Germany: Springer Verlag Publishers.

Taylor, R. C. and Dodd, S. G. (2013) Negative impacts of hunting and suction-dredging on otherwise high and stable survival rates in curlew Numenius arquata. Bird Study 6o: 221-228.

Thaxter, C. B., Joys, A. C., Gregory, R. D., Baillie, S. R. and Noble, D. G. (2010) Hypotheses to explain patterns of population change among breeding bird species in England. Biol. Conserv. 143: 2006-2019.

Trolliet, B. (2014) Plan National De Gestion (2015-2020) Barge à queue noire (Limosa limosa). Chanteloup, France: Office National de la Chasse et de la Faune Sauvage. Downloaded from: http://www.developpementdurable.gouv.fr/IMG/pdf/PNG_BQN-1.pdf on $13 /$ II $_{15}$.

Turner, W., Rondinini, N., Pettorelli, N., Mora, B., Leidner, A. K., Szantoi, Z., Buchanan, G., Dech, S., Dwyer, J., Herold, M., Koh, L. P., Leimgruber, P., Taubenboeck, H., Wegmann, M., Wikelski, M. and Woodcock, C. (2015) Free and open-access satellite data are key to biodiversity conservation. Biol. Conserv. 182: 173-176.

Ueta, M., Antonov, A., Artukhin, Y. and Parilov, M. (2002) Migration routes of Eastern Curlews tracked from far east Russia. Ети 102: 345-348.

Valkama, J. and Currie, D. (1999) Low productivity of Curlews Numenius arquata on farmland in southern Finland: Causes and consequences. Ornis Fennica 76: 65-70.
Valkama, J., Currie, D. and Korpimäki, E. (1999) Differences in the intensity of nest predation in the curlew Numenius arquata: A consequence of land use and predator densities? Ecoscience 6: 497-504.

van Gils, J. A., Piersma, T., Dekinga, A., Spaans, B. and Kraan, C. (2006) Shellfish dredging pushes a flexible avian top predator out of a marine protected area. PLoS Biol. 4: 2399-2404.

Watts, B. D., Reed, E. T. and Turrin, C. (2015) Estimating sustainable mortality limits for shorebirds using the Western Atlantic Flyway. Wader Study 122: 37-53.

Wetlands International (2012) Waterbird population estimates. Fifth Edition. Wageningen, The Netherlands: Wetlands International.

Wetlands International (2014) What are flyways? Downloaded from http://wpe. wetlands.org/Iwhatfly on 05/10/16.

Yamamura, Y., Amano, T., Koizumi, T., Mitsuda, Y., Taki, H. and Okabe, K. (2009) Does land-use change affect biodiversity dynamics at a macroecological scale? A case study of birds over the past 20 years in Japan. Anim. Conserv. 12: 110-119.

Yang, H., Chen, B., Barter, M., Piersma, T., Zhou, C., Li, F. and Zhang, Z. (2011) Impacts of tidal land reclamation in Bohai Bay, China: ongoing losses of critical Yellow Sea waterbird staging and wintering sites. Bird Conserv. Internatn. 21: 241-259.

Yasué, M., Dearden, P. and Moore, A. (2008) An approach to assess the potential impacts of human disturbance on wintering tropical shorebirds. Oryx 42: 415-423.

Zöckler, C., Syroechkovskiy, E. E. and Atkinson, P. W. (2010) Rapid and continued population decline in the Spoon-billed Sandpiper Eurynorhynchus pygmeus indicates imminent extinction unless conservation action is taken. Bird Conserv. Internatn. 20: 95-111.

\section{JAMES W. PEARCE-HIGGINS*}

British Trust for Ornithology, The Nunnery, Thetford, Norfolk, IP24 2 PU, UK. and Conservation Science Group, Department of Zoology, University of Cambridge, Downing Street, Cambridge $C B_{2} 3 E J, U K$.

DANIEL J. BROWN, DAVID J. T. DOUGLAS, GRAEME M. BUCHANAN

RSPB Centre for Conservation Science, RSPB Scotland, 2 Lochside View, Edinburgh Park, Edinburgh EH13 $9 \mathrm{DH}$, UK. 
JOSÉ A. ALVES

Centre for Environmental and Marine Studies (CESAM), Department of Biology, University of Aveiro, Campus Universitário de Santiago, 3810-193 Aveiro, Portugal and University of Iceland, South Iceland Research Centre, Fjolheimar, IS-80o Selfoss, Iceland.

\section{MARIAGRAZIA BELLIO}

Australasian Wader Studies Group, clo 58 Kirby Flat Road, Yackandanah, VIC 2749, Australia.

\section{PIERRICK BOCHER}

Laboratory Littoral Environnement et Sociétés, UMR6250, CNRS-ULR, University of La Rochelle, 17000 La Rochelle, France.

ROB P. CLAY

WHSRN Executive Office / Oficina Ejecutiva de la RHRAP, Rodríguez de Francia 869, Asunción, Paraguay.

JESSE CONKLIN, NATHAN R. SENNER

Conservation Ecology Group, Groningen Institute for Evolutionary Life Sciences (GELIFES), University of Groningen, PPOP.O. Box 11103, 9700 CC Groningen, The Netherlands.

NICOLA CROCKFORD

RSPB, The Lodge, Sandy, Bedfordshire SG19 2DL, UK.

PETER DANN

Research Department, Phillip Island Nature Parks, P.O. Box 97, Cowes, Phillip Island, Victoria, 3922, Australia.

\section{JAANUS ELTS}

University of Tartu / Estonian Ornithological Society, Veski 4, 51005 Tartu, Estonia.

CHRISTIAN FRIIS

Canadian Wildlife Service, 4905 Dufferin St, Toronto, Ontario $\mathrm{M}_{3} \mathrm{H}_{5} \mathrm{~T}_{4}$, Canada.

RICHARD A. FULLER

School of Biological Sciences, University of Queensland, Brisbane, Queensland 4072, Australia.

JENNIFER A. GILL

School of Biological Sciences, University of East Anglia, Norwich Research Park, Norwich, UK.

\section{KEN GOSBELL}

Australasian Wader Studies Group, clo 1/19 Baldwin Road, Blackburn, VIC 3130, Australia.

\section{JAMES A. JOHNSON}

U.S. Fish and Wildife Service, Migratory Bird Management, 1011 East Tudor Road, MS 201, Anchorage, Alaska 99503, USA.

\section{ROCIO MARQUEZ-FERRANDO}

Department of Wetland Ecology, Estación Biológica de Doñana-CSIC, Avda Américo Vespucio s/n, 41092, Sevilla, Spain. 
JOSE A. MASERO

Department de Anatomy, Cell Biology and Zoology, University of Extremadura, Avenida de Elvas s/n, o6071 Badajoz, Spain.

DAVID S. MELVILLE

1261 Dovedale Road, RD 2 Wakefield, Nelson 7096, New Zealand.

SPIKE MILLINGTON

EAAF Partnership Secretariat, 3 F Bon-dong G-Tower, 175 Art center-daero (24-4 Songdo-dong), Yeonsu-gu, Incheon 406-840, Republic of Korea.

CLIVE MINTON

Australasian Wader Studies Group, clo 165 Dalgety Road, Beaumaris, 3193 Australia.

TAEJ MUNDKUR

Wetlands International, PO Box 471, 6700 AL Wageningen, The Netherlands.

ERICA NOL

Department of Biology, Trent University, Peterborough, ON K9J 7B8, Canada.

HANNES PEHLAK

Institute of Agricultural and Environmental Sciences, Estonian University of Life Sciences,

Kreutzwaldi 5, Tartu 51014, Estonia.

THEUNIS PIERSMA

Conservation Ecology Group, Groningen Institute for Evolutionary Life Sciences

(GELIFES), University of Groningen, PPOP.O. Box 11103, 9700 CC Groningen,

The Netherlands and NIOZ Royal Netherlands Institute for Sea Research,

Department of Coastal Systems and Utrecht University, PO Box 59, 1790 AB Den Burg,

Texel, The Netherlands.

\section{FRÉDÉRIC ROBIN}

Ligue pour la Protection des Oiseaux, Fonderies Royales, 17300 Rochefort, France.

DANNY I. ROGERS

Arthur Rylah Institute for Environmental Research, Heidelberg, Victoria, Australia.

DANIEL R. RUTHRAUFF

U.S. Geological Survey, Alaska Science Center, 4210 University Dr., Anchorage, AK 99508, USA.

JUNID N. SHAH

Environment Agency - Abu Dhabi (EAD), P.O Box: 45553 Al Mamoura Building (A),

Muroor Road, Abu Dhabi, United Arab Emirates.

ROB D. SHELDON

RDS Conservation, clo 78 Riverdene Rd, Ilford, IGI $2 E A, U K$.

SERGEJ A. SOLOVIEV

Department of Chemistry, Omsk State University, St. Prospect Mira 55a, 644077 Omsk, Russian Federation. 
PAVEL S. TOMKOVICH

Department of Ornithology, Zoological Museum, Moscow State University, Bolshaya Nikitskatya St., 6, 125009 Moscow, Russian Federation.

YVONNE I. VERKUIL

Chair International Wader Study Group, Conservation Ecology Group, Groningen Institute for Evolutionary Life Sciences (GELIFES), University of Groningen, P.O. Box 11103, 9700 CC Groningen, The Netherlands.

*Author for correspondence; e-mail: james.pearce-higgins@bto.org

Received II January 2016; revision accepted 19 December 2016 